\title{
Radioisotopic age, formation, and preservation of Late Pleistocene human footprints at \\ Engare Sero, Tanzania
}

Liutkus-Pierce, C.M. ${ }^{1}$, Zimmer, B.W. ${ }^{1}$, Carmichael, S.K. ${ }^{1}$, McIntosh, W. ${ }^{2}$, Deino, A. ${ }^{3}$, Hewitt, S.M. ${ }^{1}$, McGinnis, K.J. ${ }^{1}$, Hartney, T. ${ }^{1}$, Brett, J.4 ${ }^{4}$ Mana, S.5, Deocampo, D. ${ }^{6}$, Richmond, B.G. ${ }^{7}$, Hatala, K. ${ }^{8}$, Harcourt-Smith, W.9, Pobiner, B.10, Metallo, A.11, Rossi, V. ${ }^{11}$

${ }^{1}$ Appalachian State University, Dept. of Geology, Boone, NC 28608, USA

${ }^{2}$ New Mexico Institute of Mining and Technology, Geochronology Research Lab, Socorro, NM 87801, USA

3Berkeley Geochronology Center, Berkeley, CA 94709, USA

${ }^{4}$ Pennsylvania Institute for Conservation Education, Elysburg, PA 17824, USA

${ }^{5}$ Salem State University, Dept. of Geological Sciences, Salem, MA 01970, USA

${ }^{6}$ Georgia State University, Dept. of Geosciences, Atlanta, GA 30303, USA

7The American Museum of Natural History, Dept. of Anthropology, New York, NY 10024, USA

8Max Planck Institute for Evolutionary Anthropology, D-04103 Leipzig, Germany

${ }^{9}$ City University of New York, Dept. of Anthropology, New York, NY 10016, USA

${ }^{10}$ The Smithsonian Institution, Dept. of Anthropology, Washington, DC 20560, USA

${ }^{11}$ The Smithsonian Institution, Digitization Program Office, Washington, DC 20560, USA 
Corresponding author: Cynthia M. Liutkus-Pierce, liutkuscm@appstate.edu

Permanent address: Department of Geology, Appalachian State University, P0 Box 32067, Boone, NC 28608, USA 


\section{Abstract}

We report on the radioisotopic age, formation, and preservation of a late Pleistocene human footprint site in northern Tanzania on the southern shore of Lake Natron near the village of Engare Sero. Over 400 human footprints, as well as tracks of zebra and bovid, are preserved in a series of volcaniclastic deposits. Based on field mapping along with geochemical and grain-size analyses, we propose that these deposits originated as proximal volcanic material from the nearby active volcano, Oldoinyo L'engai, and were then fluvially transported to the footprint site. Stable isotope results $\left(\delta^{18} \mathrm{O}\right.$ and $\left.\delta^{13} \mathrm{C}\right)$ suggest that the footprints were originally emplaced on a mudflat saturated by a freshwater spring and were later inundated by the rising alkaline waters of Lake Natron. We employed the ${ }^{40} \mathrm{Ar} /{ }^{39} \mathrm{Ar}$ and ${ }^{14} \mathrm{C}$ dating methods to investigate the age of the site and determined that the footprint level is older than $5760 \pm 30 \mathrm{yrs} \mathrm{BP}$ and younger than $19.1 \pm 3.1 \mathrm{ka}$. These radioisotopic ages are further supported by stratigraphic correlations with previously documented debris avalanche deposits and the stable isotope signatures associated with the most recent highstand of Lake Natron. Since modern humans (Homo sapiens) were present in Africa ca. 200 ka, Engare Sero represents the most abundant and best-preserved footprint site of anatomically modern Homo sapiens currently known in Africa. Fossil footprints are a snapshot in time, recording behavior at a specific moment in history; but the actual duration of time captured by the snapshot is often not well defined. Through analog experiments, we constrain the depositional window in which the prints were made, buried, and ultimately preserved to within a few hours to days or months.

Keywords: Engare Sero, hominin, footprints, Lake Natron, Pleistocene 


\section{Introduction}

Fossil human footprint sites constitute unique records of behavior at specific moments in deep time, providing information otherwise unavailable in the fossil record. Experimental studies have demonstrated that individual footprint morphologies and assemblages of footprints can reveal data on foot anatomy, body size, gait kinematics, and possibly other behavioral traits of our bipedal ancestors (e.g., Day and Wickens, 1980; Tuttle et al., 1990; Raichlen et al., 2008, 2010; Bennett et al., 2009; Crompton et al., 2012; Bennett and Morse, 2014; Dingwall et al., 2013; Hatala et al., 2013, 2016). Additionally, studies of the geology surrounding footprint sites (hominin and other) can provide clues to local paleoenvironment and preservation mechanisms (e.g., Leakey and Hay, 1979; Laporte and Behrensmeyer, 1980; Hay, 1987; Deocampo, 2002; Ashley and Liutkus, 2002; Scott et al., 2010). Unlike most paleoecological data that are time-averaged over years or even millennia, footprints and the associated paleoenvironmental indicators preserved in footprinted layers can provide unique information about the environment in which the printmakers lived on the scale of hours to days (e.g., Cohen et al. 1991, Webb et al. 2006; Roach et al., 2016). Late Quaternary Homo sapiens footprint sites ( $<200 \mathrm{ka})$ are found throughout the world, and have recently been documented in South America (Aramayo, 2009), Mexico (Gonzalez et al., 2006), Nicaragua (Schminke et al., 2009), South Korea (Kim et al. 2010), Europe (Duday and Garcia, 1983; Pastoors et al., 2016), Australia (Webb et al., 2006) and many other locations (see review by Bennett and Morse, 2014). Numerous Homo sapiens footprint sites have been documented in Africa, including in Namibia (Kinahan, 1996; Morse et al., 2013; Bennett et al., 2014) and South Africa (Roberts, 2008).

Here, we report on the age, formation, and preservation of an exceptionally well-preserved late Pleistocene human footprint site in northern Tanzania on the southern shore of Lake Natron near the village of Engare Sero. Field research at the Engare Sero footprint site began in August 2009 and, since that time, over 400 human footprints have been uncovered making it the largest 
assemblage of late Pleistocene Homo sapiens prints in Africa. What is equally remarkable is the exquisite preservation of these footprints in conjunction with the detailed geologic history recorded within the footprinted substrate.

\section{Site Location and Regional Geology}

The Engare Sero site (Fig. 1) is located in northern Tanzania, on the southern shore of Lake Natron within the Natron-Engaruka explosion crater area. The site is bounded on the west by the Nguruman Escarpment, the western border fault of the East African Rift (EAR) in southern Kenya and northern Tanzania, and on the east by two extinct shield volcanoes, Gelai and Ketumbeine (Dawson and Powell, 1969; Dawson, 2008). The area is volcanically active due to lithospheric thinning and extension along the rift since its inception during the Pliocene (Dawson, 2008). The volcanic features within this region vary dramatically in age, composition, and size, ranging from late Miocene and Pliocene shield volcanoes (such as Essimingor; Mana et al., 2012, and Gelai; Dawson, 1962) to younger intermediate composite and carbonatitic volcanoes (e.g., Oldoinyo L'engai; Dawson, 1962) and smaller tuff cones, rings, and explosion craters (e.g., Loolmurwak Crater; Dawson and Powell, 1969)(Fig. 1). The tuff cones, rings, and explosion craters exhibit phreatomagmatic textures such as wet pyroclastic surge deposits with high lithic concentrations and accretionary lapilli, suggesting that groundwater has been present and relatively shallow within the rift basin throughout its evolution. The presence of abundant groundwater was likely one of the features that attracted early modern humans to the rift basin (Cuthbert and Ashley, 2014). Wet surge or ash deposits are ideal locations for footprint preservation (both hominin and animal), as they can preserve details not generally seen in prints in coarser grained sediments (Hay, 1986). 


\section{Methodology}

\subsection{Field measurements}

When our research team first visited the Engare Sero footprint site in 2009, approximately $125 \mathrm{~m}^{2}$ of footprinted surface had already been exposed by natural surface erosion and 56 human tracks were visible. Formal excavation from 2009 to 2012 exposed an additional $175 \mathrm{~m}^{2}$ of the footprinted layer, which yielded an additional $~ 350$ human tracks (Fig. 2). The entire footprinted surface was documented through high-resolution photogrammetry. Because the site was partially exposed at the time of discovery and subject to continuous natural weathering and erosion, this method was deemed the most effective immediate approach for site preservation (Bennett et al., 2013). Photogrammetry was also employed to capture detailed imagery of individual footprints to supplement physical field measurements and to establish a baseline morphology against which subsequent imagery could be compared in order to evaluate rates of site degradation. Photogrammetry measurements of the individual prints have a resolution of $+/-0.1 \mathrm{~mm}$ while the site map's resolution is $+/-0.2 \mathrm{~mm}$.

Starting from the footprint site, distinct lithologic strata were tracked and documented across the basin between Oldoinyo L'engai and Lake Natron to assess the individual deposit's lateral extent, thickness, bedforms, and stratigraphic relationship to other known deposits (e.g., yellow tuff agglomerate (YTA), per Dawson, 1959; the "zebra debris avalanche" per Kervyn et al., 2008). Samples of these strata were collected from sites both proximal to the footprints and at distal locations to be mineralogically and geochemically compared and correlated. Samples were also collected from nearby volcanoes to be compared with the footprint strata to constrain the potential sources.

Samples of all layers exposed at the footprint site were collected for ${ }^{40} \mathrm{Ar} /{ }^{39} \mathrm{Ar}$ dating. In an effort to conserve the pristine nature of the site, sample collection was done outside of the 
footprinted area, but within units along which lateral continuity with the printed layers could be maintained. Additionally, a shell sample was collected from these proximal beds for ${ }^{14} \mathrm{C}$ dating and several leaf and thorn impressions were collected to assist in paleoenvironmental reconstructions.

\subsection{Mineralogy and Geochemistry}

Mineralogy and geochemistry of the footprinted substrates were determined using a variety of techniques. Bulk mineralogy was determined by powder X-ray diffraction (XRD) using a Shimadzu XRD 6000 X-ray diffractometer with a PDF/4+ Minerals database at Appalachian State University. Samples were ground in a diamonite mortar and pestle and scanned at $5-80^{\circ} 2 \theta$, using a $\mathrm{Cu}$ tube $\mathrm{X}$-ray source operated at $40 \mathrm{kV}$ and $30 \mathrm{~mA}$. Identification of individual minerals and analysis of petrographic textures was determined by optical petrography, cathodoluminescence (CL) microscopy, and scanning electron microscopy with energy dispersive X-ray microanalysis (SEMEDS). CL was performed using a RELIOTRON cold cathode system in the Geology Department at Appalachian State University, and SEM-EDS analysis was performed on a FEI Quanta 200 environmental scanning electron microscope with an attached EDAX energy-dispersive X-ray spectrometer in the Dewel Microscopy Facility at Appalachian State University. X-ray fluorescence (XRF) data were collected in the Department of Geosciences at Georgia State University on a Rigaku 3270 wavelength-dispersive XRF spectrometer, operated at $50 \mathrm{kV}$ and $50 \mathrm{~mA}$.

\subsection{Electron Microprobe}

Analyses of biotite crystals were performed using a Cameca SX-100 electron microprobe with three wavelength-dispersive spectrometers. Analytical conditions used were $15 \mathrm{kV}$ acceleration voltage, $20 \mathrm{nA}$ beam current, and $10 \mu \mathrm{m}$ beam size (see Supplemental Data, Table S1).

Initially, polished bulk samples of the MRL (sample CML-ES-13-005) were examined using backscattered electron imaging, and then quantitative analyses were carried out on biotite and other mineral phases. Subsequently, twenty biotite crystals from sample CML-ES-13-005 (numbers 
ranging from FPB-1 to FPB-20) were selected for argon analysis and cleaned in dilute HF. As described in the ${ }^{40} \mathrm{Ar} /{ }^{39} \mathrm{Ar}$ methods section, these crystals were cut into six to eight pie-slice-shaped pieces, and one slice from each crystal was analyzed by electron microprobe. Cleavage faces and cleavage-perpendicular grain edges were examined by backscattered electron imaging, and quantitative analyses were performed on unpolished cleavage faces.

\subsection{Stable Isotope Analysis}

Stable isotope values of bulk carbonate were derived from 3 different samples of the lower footprinted layer (or LFL) and 2 samples of the mica rich layer (or MRL). Stable isotope analyses were run in the Stable Isotope Laboratory at Rutgers University in the Department of Earth and Planetary Sciences. Samples were loaded into a multi-prep device and were reacted in $100 \%$ phosphoric acid at $90^{\circ} \mathrm{C}$ for 13 minutes before being analyzed on the Micromass (Optima) dual-inlet mass spectrometer. Both $\delta^{13} \mathrm{C}$ and $\delta^{18} \mathrm{O}$ values were obtained and the values reported versus the Vienna Pee Dee Belemnite (V-PDB) by analysis of a lab standard calibrated to the National Bureau of Standards (NBS) \#19 with values of $1.95 \%$ and $-2.20 \%$ or $\delta^{13} \mathrm{C}$ and $\delta^{18} \mathrm{O}$, respectively (Coplen et al., 1983). Standard deviation $(1-\sigma)$ of the standards was $0.08 \%$ and $0.05 \%$ for $\delta^{18} \mathrm{O}$ and $\delta^{13} \mathrm{C}$, respectively. Equation 1 (Craig, 1965) was used to calculate the temperature and/or geochemical conditions during the time of calcite precipitation:

$$
T\left({ }^{\circ} \mathrm{C}\right)=16.9-4.2\left(\delta^{18} \mathrm{O}_{\text {calcite }}-\delta^{18} \mathrm{O}_{\text {water }}\right)+0.13\left(\delta^{18} \mathrm{O}_{\text {calcite }}-\delta^{18} \mathrm{O}_{\text {water }}\right)^{2} \quad \text { Equation } 1
$$

where the $\delta^{18} \mathrm{O}_{\text {calcite }}$ is expressed as V-PDB and $\delta^{18} \mathrm{O}_{\text {water }}$ is the value of the water in which the carbonate formed converted from V-SMOW to V-PDB by subtracting $0.22 \%$ (Coplen et al., 1983).

\subsection{Grain Size Analysis}

Distribution of grain sizes from the unit overlying the footprints (the mica rich layer, or MRL) was determined by photographing thin sections of the MRL on an Olympus SZX12 light 
microscope and processing the resulting image with Marker-Controlled Watershed Segmentation analysis using Matlab (Trauth, 2010). The size of particles within the image was determined by finding the number of pixels contained within the boundary of each object ( $N=1065$ grains) through watershed transformation. These values were then organized by grain area (i.e., a proxy for grain size of the particles) and plotted on a histogram.

\subsection{Radioisotopic Dating}

A variety of radiogenic dating mechanisms were used to constrain the age of the footprinted substrate, including ${ }^{40} \mathrm{Ar} /{ }^{39} \mathrm{Ar}$ of various K-bearing minerals (biotite and hornblende) at two laboratories (the Berkeley Geochronology Center, and the New Mexico Geochronology Research Lab) as well as ${ }^{14} \mathrm{C}$ dating of shell material at the Lawrence Livermore National Laboratory.

\subsection{1 ${ }^{40} \mathrm{Ar} /{ }^{39} \mathrm{Ar}$ Dating (Berkeley Geochronology Center)}

Six samples of MRL were analyzed by the ${ }^{40} \mathrm{Ar} /{ }^{39} \mathrm{Ar}$ dating method (samples 'Bio-MicaTuff,' 'SMT,' 'ES13-1', 'ES13-2, 'ES13-3,' and 'MR001'). Hornblende crystals were studied in ES13-2, while biotite crystals were the target material in the other five samples. Hornblende was unaltered, but biotite crystals exhibited varying degrees of bleaching; only the freshest-appearing, blackest biotite books were used in this study.

Crystals (0.4-3.0 mm) were hand-selected from gently crushed whole-rock material, and cleaned in distilled water in an ultrasonic bath. The mineral separates were then irradiated in the Cd-lined, in-core CLICIT facility of the Oregon State University TRIGA reactor 0.07 hours for samples Bio-MicaTuff, SMT, and MR001, and 0.02 hours for samples ES13-1 to -3). Sanidine from the Alder Creek Rhyolite was used as a mineral standard to evaluate neutron fluence, with a reference age of 1.202 Ma (Renne et al., 1998 adjusted for Kuiper et al., 2008). 
${ }^{40} \mathrm{Ar} /{ }^{39} \mathrm{Ar}$ extractions were performed using a rampable 50 -Watt $\mathrm{CO}_{2}$ laser, fitted with a circular integrator lens, to incrementally heat individual biotite crystals for 30 seconds and liberate trapped argon. Evolved gasses were exposed for several minutes to an approximately $-130^{\circ} \mathrm{C}$ cryosurface to trap $\mathrm{H}_{2} 0$, and a GP-50 SAES getters to remove reactive compounds $\left(\mathrm{CO}, \mathrm{CO}_{2}, \mathrm{~N}_{2}, \mathrm{O}_{2}\right.$, and $\mathrm{H}_{2}$ ), then measured for five noble gasses in a Noblesse 5 -collector sector-magnet mass spectrometer, configured with one axial Faraday detector and four off-axis, symmetrically arrayed ETP ion counters. Duration of measurement was $\sim 600$ seconds, involving simultaneous measurement of ${ }^{40} \mathrm{Ar},{ }^{39} \mathrm{Ar},{ }^{37} \mathrm{Ar}$, and ${ }^{36} \mathrm{Ar}$ on separate ion counters. In some of the experiments, peak hopping was employed to periodically position ${ }^{38} \mathrm{Ar}$ on the same ion counter as ${ }^{40} \mathrm{Ar}$; in the balance of the experiments, measurement of ${ }^{38} \mathrm{Ar}$ was omitted, as it has no influence on the ages and detracts from time spent on measuring critical isotopes.

All signals were normalized to the ${ }^{40} \mathrm{Ar}$ ion counter. ${ }^{36} \mathrm{Ar}$ signal normalization was achieved through periodic measurement of the ${ }^{40} \mathrm{Ar} /{ }^{36} \mathrm{Ar}$ ratio of air argon (298.6; Lee et al., 2006) inlet from an air reservoir pipetting system. Air abundance from air aliquots experiments was closely matched to the unknowns, yielding $2.3 \times 10^{-15}$ moles ${ }^{40} \mathrm{Ar} .{ }^{37} \mathrm{Ar}$ and ${ }^{39} \mathrm{Ar}$ signal normalizations were achieved through periodic measurement of ${ }^{40} \mathrm{Ar}$ from a static gas sample on relevant detectors in a systematic round-robin peak-hopping procedure. Procedural blanks, matching sample gas extractions precisely but without firing the laser, were run every 2-3 analyses and typically yielded $\sim 6 \times 10^{-17}, 4 \times 10^{-19}$, and $4 \times 10^{-19}$ moles of ${ }^{40} \mathrm{Ar}$, ${ }^{39} \mathrm{Ar}$, and ${ }^{36} \mathrm{Ar}$, respectively. For further details of the dating procedure refer to Deino et al. (2010).

\subsection{2 ${ }^{40} \mathrm{Ar} /{ }^{39} \mathrm{Ar}$ Dating (New Mexico Geochronology Research Lab)}

Eighteen crystals of biotite from the MRL were analyzed by the ${ }^{40} \mathrm{Ar} /{ }^{39} \mathrm{Ar}$ incremental heating methods at the New Mexico Geochronology Research Laboratory. Initial electron microprobe observations of a selection of biotite crystals prepared in cross section revealed detrital 
and/or authigenic clay and silt grains in some cleavages within the grains, apparently introduced during fluvial reworking and deposition. A special procedure was developed to minimize this problem, and also to allow electron microprobe analysis of individual dated biotite crystals. Twenty of the largest and blackest biotite crystals were separated, numbered FPB-1 to FPB-20, and cleaned in dilute (2\%) HF in a low-power ultrasonic cleaner. Each grain was then cut with a scalpel into six to eight pie-slice-shaped fragments, which were examined optically for signs of alteration or silt in cleavages, resulting in rejection of two of the crystals. For the remaining eighteen crystals, one crystal slice was reserved for major-element analysis on the electron microprobe, and the remaining slices were irradiated, keeping slices from each crystal separated. The biotites were irradiated in machined aluminum discs along with flux monitors (Fish Canyon Tuff sanidine, 28.201 Ma, Kuiper et al., 2008) for 20 minutes at the USGS TRIGA reactor in Denver, CO.

Following irradiation, samples and monitors were analyzed using a Thermo Argus VI multicollector mass spectrometer. Analytical parameters are summarized in Supplemental Data (see footnotes of Table S7). Flux monitor sanidines were fused using a 75-watt $\mathrm{CO}_{2}$ laser and biotites were step-heated using a 45 -watt $810 \mathrm{~nm}$ diode laser. Intracrystal age variations were assessed by separately step-heating individual slices for two of the eighteen biotite crystals, and by step heating two aliquots of three to four slices for an additional five crystals. For each of the remaining eleven crystals, all slices from each crystal were step-heated together, yielding a single age spectrum for each crystal. The majority of step-heating analyses included only three steps at increasing power, with an initial step at 0.3 to 0.5 watts to remove low-radiogenic-yield gas, a second step at 2 watts to extract the majority of the argon, and a third step at 3 watts. This stepheating procedure was chosen to maximize the precision of the 2-watt step, although the small number of steps limits the ability to assess discordance in the spectra. Plateau ages were calculated for all but one of the step-heating analyses; in each case the plateau age is dominated by the age of the 2-watt step. 


\subsection{3 ${ }^{14} \mathrm{C}$ dating (Lawrence Livermore National Laboratory)}

A sample of shell was analyzed for ${ }^{14} \mathrm{C}$ by the Center for Accelerator Mass Spectrometry (CAMS) at Lawrence Livermore National Laboratory. The shell sample was sonicated prior to analysis in order to remove surface debris. Two duplicate samples were analyzed, and despite sonication, the samples appeared discolored. Sample preparation backgrounds were subtracted based on measurements of samples of ${ }^{14} \mathrm{C}$-free calcite. Backgrounds were scaled relative to sample size. Radiocarbon concentration was provided as fraction of modern, $\mathrm{D}^{14} \mathrm{C}$, and conventional radiocarbon age. The quoted age in radiocarbon years uses the Libby half-life of 5568 years and follows the conventions of Stuiver and Polach (1977).

\subsection{Footprint Stability Analysis}

Artificial footprints were created in the lab to assess their relative stability when created under different environmental conditions and/or exposed to rewetting. Plastic trays (56 $\mathrm{cm}^{2}$ area) were filled with 50g of unconsolidated modern ash (2010) from Oldoinyo L'engai $(\phi=2-2.5)$. The individual trays were then saturated (2:1 ash/water mass ratio) with alkaline water solutions, mixed to approximate the chemistries of Lake Natron, Natron-area freshwater springs, and alkaline hot springs, by lightly spraying the trays with the solution to simulate rainfall (Table 1; Deocampo, 2002; Warren, 2006). Tap water was used as a blank to simulate meteoric water. Three-fingered impressions were manually pressed into the saturated sediments and allowed to dry at room temperature. The prints were rewet to various levels of saturation after time durations of 1 week, 3 months, and 6 months to assess the permanence of the cementation created by the different alkali solutions and their susceptibility to remobilization.

\section{Results}




\subsection{Geology of the Engare Sero Footprint Site}

Both human and animal prints have been identified at Engare Sero, scattered over an area covering approximately $1 \mathrm{~km}^{2}$ (Fig. 1). The surface that contains the human prints is a $\sim 300 \mathrm{~m}^{2}$, NESW trending exposure of volcaniclastic deposits that sits in an ephemeral channel of the Engare Sero River. To the south, the site grades into the river channel where erosion has destroyed most of the footprinted surface. To the north, however, the site is covered by sand dunes composed of mainly olivine and hornblende (minerals eroded from nearby volcanic centers). The human footprint trails begin $\sim 20 \mathrm{~m}$ south of the dune line and continue northeast up to and beneath the sand dunes (Fig. 2). The trails of four bovid individuals are preserved in the northwest corner of the site, a few meters from the closest human prints. Several additional fossil animal trails are located $\sim 30 \mathrm{~m} \mathrm{SW}$ of the human footprint site toward the Engare Sero River channel, and several other sites containing animal footprints are located to the northwest (Fig. 1 inset).

The Engare Sero footprints are preserved in two distinct units: a lower dark gray volcaniclastic sandstone (called the lower footprint layer, or LFL) and an upper dark gray-brown volcaniclastic paraconglomerate of varying thickness, containing cobbles of varying sizes and compositions (called the "block layer" or BL). A zebra trail to the SW of the human tracks is pushed through both the BL and the LFL. However, in the area near the human prints, the exposed surface is mostly LFL, with only small pockets of BL preserved. Directly overlying the footprinted BL unit (where present) is a volcaniclastic unit called the mica rich layer, or MRL, that is distinguishable by the presence of large (up to $3 \mathrm{~cm}$ ) mica flakes. A generalized stratigraphic column is shown in Figure 3. Due to erosion and localized heterogeneity, it is rare to see this complete stratigraphic section in outcrop.

The LFL is at least $35 \mathrm{~cm}$ thick, and the lower boundary has not yet been identified. The unit exhibits weak laminar bedding with occasional grading of particles. The LFL unit is strongly 
cemented, making its surface resistant to weathering, and displays large polygonal desiccation cracks and small erosional channels (Fig. 2). A thin $(<1 \mathrm{~cm})$ veneer of mud is locally present on top of the LFL (Fig. 4a). Plant stems and root holes are preserved in the mud drape on top of the LFL (Fig 4b). Intact plant fragments are found adjacent to, and rarely in, the human prints (Fig 4c); at least one thorn impression has been identified (Fig. 4d). Rarely, small volcanic rock fragments (e.g., pebbles of basalt) can be found within the LFL. The LFL unit was also observed $\sim 1 \mathrm{~km}$ east of the site, but further identification has been limited due to weathering and lack of exposure in the Engare Sero River channel.

The BL unit has little juvenile material (e.g., ash and/or pumice) and is rich in lithic clasts. The unit regionally varies in thickness (for example, thins to the north) and is rarely present near the human footprints in the LFL. The matrix of the BL unit rarely exceeds $\sim 10 \mathrm{~cm}$ in thickness, but contains clasts as large as $1 \mathrm{~m}$ in diameter that often extend above the top of the matrix layer. This unit hosts a large number of volcanic cobbles (Fig. 5a) with a range of compositions (e.g., basalt, phonolite, etc.) and sizes (1-100cm diameter), though many of the cobbles have been eroded away leaving impressions in the BL. Where exposed, the surface of the BL unit preserves flow ridges (Fig. 5b) and desiccation cracks (Fig. 5c), and is rarely covered by a very thin $(<1 \mathrm{~mm})$ veneer of mud. Similar to the LFL, the BL unit contains plant fragments but also preserves exquisite intact leaf fossils (Fig. 5d) and at least 2 gastropod specimens (Fig. 5e), including an aquatic species, Melanoides cf. tuberculata (Van Bocxlaer, B., pers. comm.; Scholz, H., pers. comm., Leng et al., 1999), which we analyzed for ${ }^{14} \mathrm{C}$. The BL onlaps localized deposits of the YTA (yellow tuff agglomerate per Dawson, 1959; the "zebra debris avalanche” per Kervyn et al., 2008).

The mica rich layer (MRL) has a bimodal grain size distribution, containing large biotite crystals rarely up to $3 \mathrm{~cm}$ in a fine-grained matrix. In places, the MRL contained 2 layers separated by a thin $(1-3 \mathrm{~cm})$ mud layer. The MRL unit exhibits weak laminar bedding and normal grading (Fig. 
6a). Mineral alignment is evident at the base of the unit. Grain size analysis of the MRL indicates that it is coarse-skewed (i.e., there is an excess of poorly sorted coarse grains)(Fig. 6b, c). While the upper contact of the MRL is not present due to erosion, exposures near the site indicate that the deposit is at least 40cm thick (Fig. 6a). Regional mapping by Sherrod et al. (2013) indicates mica rich lahars that are texturally and mineralogically similar to the MRL on the northern flanks of Oldoinyo L'engai (unit Qol).

\subsection{Geochemistry and Petrography}

The mineral assemblage of the LFL includes crystals of nepheline, augite, Fe-rich titanite, and leucite (Fig. 7a). Other minerals identified through SEM-EDS and XRD are presented in Table 2. Secondary calcite cement and coatings on voids and other surfaces were identified by optical and CL microscopy (Fig. 7b). The BL unit's mineral assemblage is similar, predominantly containing nepheline, augite, titanite, leucite, and Fe-rich biotite (annite). The MRL contains nepheline, augite, biotite, and rare melilite, and its texture and mineralogy (large flakes of biotite in a fine-grained matrix) makes it visually distinct from the well-sorted LFL and cobble-rich BL (Fig. 7c).

Results of electron microprobe analyses of MRL biotite are detailed in Supplemental Data (Table S1), together with analyses of standard reference materials. Initial observations of bulk sediment from the MRL revealed significant grain-to-grain compositional variation among variably fresh biotite crystals, as well as the presence of clay and/or fine sediment within the cleavages of some biotite crystals (Fig. 8 a, b). Subsequent examination and analysis of slices of crystal faces of hand-selected visually pristine biotite crystal slices (Fig. 8 c-f) indicate little alteration in most of the crystals. Although the data are slightly compromised because they were collected from crystal faces rather than polished surfaces, analytical totals are high (93-104\%) and $\mathrm{K}_{2} \mathrm{O}$ ranges from 8.9\% to $10.3 \%$. No chlorite was observed. $\mathrm{MgO}$ ranges from 10.2 to $22.2 \%$ and $\mathrm{FeO}$ ranges from 6.7 to 
9.2\%, yielding $\mathrm{Mg} / \mathrm{Fe}$ ratios ranging from 1.6 to 2.4, effectively straddling the compositional boundary $(\mathrm{Mg} / \mathrm{Fe}=2)$ between biotite and phlogopite. Two crystal slices had observable clay or silt in cleavages along the grain margin and were rejected from ${ }^{40} \mathrm{Ar} /{ }^{39} \mathrm{Ar}$ analysis(Fig. $8 \mathrm{~d}$ ); the remaining 18 biotites appeared entirely free of clay or silt. Compositional variation among the biotites selected for argon analysis was small, with $\mathrm{F}$ and $\mathrm{FeO}$ being the most variable. Figure 9 examines variation in $\mathrm{SiO}_{2}$ and $\mathrm{FeO}$ for eighteen dated crystals. Crystals in the 36-75 ka age and 85150 ka age populations $\left({ }^{40} \mathrm{Ar} /{ }^{39} \mathrm{Ar}\right.$ results presented below) have similar ranges in $\mathrm{SiO}_{2}(34-38.6 \%)$ and $\mathrm{FeO}(7-9.4 \%)$ consistent with derivation from the same eruption. Two crystals with anomalously old ages (288 ka and $350 \mathrm{ka}$ ) have a distinct combination of high $\mathrm{SiO}_{2}$ and low $\mathrm{FeO}$, consistent with them being xenocrysts derived from other eruptions, although more geochemical and dating analyses would be required to demonstrate this with any certainty.

Major, minor, and trace element signatures obtained from X-ray fluorescence (XRF) of whole rock samples provide confirmation of the similarities observed in thin section (Table S2). Trace element magmatic classification reveals a trachyandesite composition for the footprint-site sediments and a similar composition for OL-104 (Fig. 10a). Major elements ( $\mathrm{MgO}, \mathrm{Fe}_{2} \mathrm{O}_{3}$, and $\mathrm{Al}_{2} \mathrm{O}_{3}$ ) likewise show clustering of OL-104 with samples from the footprint site (Fig. 10b).

Stable isotopic values of the bulk carbonate in the LFL and MRL are distinctive (Fig. 10c). Values for the LFL are low $\left(\delta^{18} 0\right.$ ranges from -2.9 to $-4.6 \%$ V-PDB, and $\delta^{13} \mathrm{C}$ ranges from -1.4 to $2.3 \%$ V-PDB), whereas values for the MRL are higher ( $\delta^{18} \mathrm{O}$ values are $\sim 0.8 \%$ V-PDB, and $\delta^{13} \mathrm{C}$ ranges from -0.8 to $0.7 \%$ V-PDB) (Table S3). Modern $\delta^{18} \mathrm{O}$ values of meteoric water in the region vary, ranging from $\sim 4.0 \% \mathrm{~V}$-SMOW (Serengeti, $\sim 20 \mathrm{~km}$ west of Engare Sero) to $\sim 2.5 \% \mathrm{~V}$-SMOW in the lower elevations near the shores of Lake Natron (Bowen et al., 2010; Bowen and Revenaugh, 2003). 


\subsection{Age of the Footprints}

Stratigraphy constrains the age of the footprints; since the footprints are pressed into the LFL and BL layers, and since the BL layer onlaps the YTA, the footprints are therefore younger than the YTA. The YTA has been described as a Pleistocene debris avalanche, with age dates ranging from $>10$ ka to possibly $>50$ ka based on relationships to dated lake levels (Hillaire-Marcel et al., 1987). The footprints, however, were buried by the MRL. Therefore, the footprints must be younger than the LFL and BL, but very close in age to the deposition of the MRL, given their fragile nature as discussed below.

A summary of the radioisotopic ages and their associated methodologies (including minerals analyzed) conducted in this study is provided in Table 3 . We obtained ${ }^{40} \mathrm{Ar} /{ }^{39} \mathrm{Ar}$ analyses on hornblende crystals within the LFL and biotite crystals within the MRL. Considerable scatter in single-grain ages was observed, well beyond that attributable to measurement uncertainty in the gas analysis alone. As described below, this phenomenon is attributed to the presence of xenocrysts (older contaminant grains) or excess ${ }^{40} \mathrm{Ar}$ (as a component of the grains in the crystals at the point of pyroclastic fallout).

Analytical data and incremental heating release spectra for the hornblende crystal analyses (from the LFL) are provided in Supplemental Data (Fig. S1, Table S4). All grains yielded ages that were far older than is geologically reasonable (apparent age plateaus from 65-23 Ma), whereas the probable source vent, Oldoinyo L'engai, is likely not much older than $0.8 \mathrm{Ma}$ (Sherrod et al., 2013). Thus, the hornblende examined could be partially degassed grains of deep-seated origin, or excess ${ }^{40}$ Ar-rich magmatic phenocrysts.

Analytical data and incremental release apparent-age spectra for the biotite experiments from the MRL analyzed by Berkeley Geochronology Center (BGC) are provided in Supplemental Data (Figs. S2-S6, Tables S5, S6). A broad range in ages is exhibited (283-19 ka). Sample Bio- 
MicaTuff was analyzed most extensively; of the 19 grains analyzed, 15 yielded plateaus. The ageprobability distribution of this sample (Fig. 11) exhibits a sharply defined principal mode at $\sim 20 \mathrm{ka}$, with an extensive tail toward older ages. The four grains composing this mode give a weightedmean age of the isochron results of $19.1 \pm 3.1 \mathrm{ka}$. The broad age distribution of the Bio-MicaTuff sample results is interpreted as reflecting varying degrees of excess ${ }^{40} \mathrm{Ar}$ within crystals or xenocrysts (perhaps partially degassed). If so, then the youngest material will be least affected by these biases and will be closest to the true eruption age. However, even the youngest mode in this complicated situation may not be entirely free of the age-biasing effects of xenocrysts or excess ${ }^{40} \mathrm{Ar}$. There may also be a time lag between the emplacement of ash on the flanks of the volcano and final redistribution of this material to the final depositional site. Therefore, the age of the youngest mode, $19.1 \pm 3.1 \mathrm{ka}$, must be considered the maximum age for the MRL (i.e., the true depositional age could be even younger than this). The other three samples, analyzed fewer times, provide ages falling within the tail of the Bio-MicaTuff sample, and do not help further constrain the eruptive age.

Age spectra from 18 biotite crystals from sample CML-ES-13-005 of the MRL, analyzed at the New Mexico Geochronology Research Lab (NMGRL), are summarized in Supplemental Data (Figs. S7-S10, Table S7). All but one of the 32 analyses of the 18 crystals yielded plateau ages (Table S7). Plateau ages are preferred over isochron analyses for these biotite results, as discussed in the Supplemental Data text. Multiple analyses of single slices of two crystals suggest no significant variation in age within grains, although small sample size limited precision (as detailed in Supplemental Data text, Figs. S7, S10, Table S7). Further evidence for age homogeneity within individual grains comes from paired plateau ages from replicate analyses of 5 samples, each with 35 slices. Four of the five paired replicate analyses agree within $1-\sigma$ error, while ages of the fifth pair differ by $\sim 1.5-\sigma$ (Supplemental Data text, Figs. S8, S10, Table S7). Figure 12 combines plateau ages from these 5 pairs of analyses with data from 10 crystals where, for each crystal, all slices were combined and step heated together (age spectra in Fig. S9). 
Overall, multi-slice plateau ages (20 analyses of 15 crystals) range from 36 to 353 ka (Fig. 12). The probability distribution plot of these data indicates two main modes near $48 \mathrm{ka}$ and 100 ka (Fig. 12), and two older modes near $290 \mathrm{ka}$ and $350 \mathrm{ka}$, each defined by results from a single crystal. The youngest group of plateau ages, which includes six analyses from four biotite crystals, has a weighted mean age of $48 \pm 8 \mathrm{ka}$. As discussed elsewhere, this age determination represents a maximum depositional age for the MRL. Excluding less-precise single-slice analyses, the plateau ages from all other biotite crystals are significantly older. The two crystals with the oldest apparent ages (FPB-14, 350 ka and FPB-20, $288 \mathrm{ka}$ ) may represent xenocrystic grains incorporated from the eruptive vent, an interpretation also supported by their somewhat distinctive mineral composition (Fig. 9). The biotite crystals with 82 to 155 ka apparent ages are not compositionally distinct from the youngest population of $48 \pm 8$ ka biotite crystals. They may also be xenocrysts, or their anomalously old ages may be due to small amounts of excess ${ }^{40} \mathrm{Ar}$. Although alteration and intra-cleavage silt and clay were observed in some biotite crystals, it is unlikely to be the cause of the anomalous ages. Effects of silt or alteration would likely be heterogeneous within individual grains. The similarity of anomalously old ages from multiple analyses of individual crystals suggests that the cause must be relatively homogeneously distributed within different slices of individual grains.

In summary, the BGC and NMGRL results separately suggest maximum ages for biotite from the MRL unit of $19.1 \pm 3.1 \mathrm{ka}$ and $48 \pm 8 \mathrm{ka}$, respectively. The two results differ at the $95 \%$ confidence level, and in explanation it is noted that the results were obtained from different samples using different variations of the ${ }^{40} \mathrm{Ar} /{ }^{39} \mathrm{Ar}$ dating technique and data analysis approaches (i.e., use of plateau vs. isochron ages), and as such are not directly comparable. If both results are considered equally valid and true maximum ages for the biotites dated, then the younger of the two results should be used as the maximum age constraint for the MRL. Further, more comprehensive 
work will be needed to refine the age of the MRL. Nevertheless, both studies conclude that biotite in the MRL was erupted in the latest Pleistocene to possibly as young as the Holocene.

Two other radioisotopic dating attempts provided inconclusive results. A plant fragment was found sandwiched between the human footprints and the overlying MRL. The fragment was discovered when the MRL was removed in order to uncover more human footprints beneath the sand dunes to the north. It was in situ, and an age on that plant fragment would have represented the time after the BL was emplaced and before the MRL covered the region, providing an exceptional opportunity to date the window of time during which the footprints were created. Unfortunately, during preparation it was discovered that the plant material had been entirely replaced and contained no dateable carbon.

In an additional attempt to better constrain the age of the footprinted units, the Melanoides cf. tuberculata specimen collected from the top of the BL unit was also analyzed for radiocarbon. Duplicate analyses from the same sample yielded conventional radiocarbon age estimates of $5135 \pm$ 30 yrs and $5760 \pm 30$ yrs BP. However, the reliability of this result is in question because: 1) The shell sample was heavily cemented with authigenic cement, which the lab tried to remove through sonication. Lab results confirmed, however, that it was not possible to remove all of the cemented calcite from the samples prior to analysis. Contamination by secondary cement would induce an error toward a more modern age (Vita-Finzi and Roberts, 1984). 2) Melanoides cf. tuberculata makes its shell out of aragonite (Leng et al., 1999) and alteration of aragonite to calcite significantly affects the accuracy of radiocarbon measurements (Chappell and Polach, 1972; Vita-Finzi and Roberts, 1984). However, each of these processes produces a shift of the result to ages that are too young, therefore the oldest radiocarbon age is considered a minimum age of the shell. The footprint level must be older than this result. 
Based on the radioisotopic dating results, we infer that the footprint level is therefore older than $5760 \pm 30$ yrs BP and, if the MRL was deposited soon after the footprints were emplaced as discussed below, the prints are younger than $19.1 \pm 3.1 \mathrm{ka}$. These constraints are, in part, consistent with a recent paper by Balashova et al. (2016) who suggest a Holocene age for the footprints based on stratigraphic relationships, but differ by permitting an age into the latest Pleistocene.

\subsection{Footprint stability}

Regardless of the chemistry or duration of drying, all trays of ash were completely remobilized (i.e., the prints were destroyed) when wetted to saturation (2:1 ash/water mass ratio). This level of saturation represents a rainfall event with an accumulation of approximately $0.5 \mathrm{~cm}$. At this ratio, ash remobilization was not immediate and the higher alkalinity samples (using hot spring and Lake Natron water chemistries, Table 1) took $\sim 1$ hour to fully remobilize. Lower ratios (i.e., 1:1) resulted in immediate and complete remobilization. Rewetting to ash/water ratios of 4:1 did not result in full remobilization. However, significant print detail was lost along the print margins and in basal areas of accumulation. Rewetting at 6:1 ash/water ratio caused no significant change.

\section{Discussion}

\subsection{Source and depositional environment of the $L F L, B L$, and MRL units}

Upon comparison with 8 different volcanic centers in the region, petrographic, XRD, SEMEDS and whole rock XRF geochemical analyses reveal that the LFL, BL, MRL, and YTA units, although texturally and mineralogically distinct, are most similar to deposits found on the flanks of Oldoinyo L'engai, such as sample OL-104 (Fig. 10a, b, Table 2, Table S2). Similarities in immobile trace element geochemistry between Oldoinyo L'engai, the LFL, and the BL units suggest that they likely evolved from related trachyandesitic magmas, if not the same eruptive source (Fig. 10a). 
Electron microprobe analysis indicates that the nepheline composition within the LFL is variable, suggesting either multiple sources for the nepheline or nepheline crystals from multiple eruptions. Both units (LFL and BL) resemble sample OL-104 in bulk mineralogy (Table 2, Fig. 10a, b), which contains large nepheline and augite crystals within a fine-grained, silica-depleted groundmass. Due to its related mineralogy and geochemistry, and similarity in texture and composition to the Qol deposits mapped on the flanks of Oldoinyo L'engai by Sherrod et al. (2013), the MRL most likely originated from Oldoinyo L'engai as well (Fig. 10a, b), although if so it has an affiliation with a slightly different magma source, consistent with basanite/nephelinite Oldoinyo L'engai sample OL105 (Fig. 10a). Oldoinyo L'engai's magmatic composition has oscillated throughout its eruptive history between phonolite, nephelinite, and natrocarbonatite (Klaudius and Keller, 2006; Dawson, 2008), and therefore variability in mineralogical composition between eruptions would not be unusual. Thus, even though the LFL and BL units are mineralogically different from the MRL unit, it is indeed possible to have the same volcanic center as their source. We note that the MRL does appear geochemically similar to Embalulu O'Sekenge (Fig. 10b), which sits west of the footprint site (Fig. 1); however Embalulu O’Sekenge is a Pleistocene explosion crater (Sherrod et al., 2013) that produced lithic-rich surge deposits with minimal juvenile material. The deposits contain magmatic mica, but it is sparse and finer $(<5 \mathrm{~mm})$ than the larger biotite in the MRL. It is, therefore, an unlikely source of the much younger biotite seen in the MRL.

The diverse composition of the nepheline within the LFL layer and biotite within the MRL, coupled with the poorly sorted, cobble rich nature of the BL, along with the silt embedded in the MRL biotite cleavage planes suggest that these units are volcanic in origin but have been reworked and/or redeposited by fluvial and/or debris flow processes. This is not unexpected, as these deposits sit within a modern ephemeral channel of the Engare Sero River, which drains from the EAR escarpment to the shores of Lake Natron as it has likely done for millennia (Dawson, 2008). 


\subsection{Lacustrine alteration and cementation of the $L F L, B L$, and MRL units}

The homogeneous texture and mudcracks on the surface of the LFL as well as intercalated mud layers suggest that this unit was deposited on a lake margin, where it could be inundated by lake transgressions and/or spring/surface waters. Abundant plant fragments found in the LFL muds and the aquatic snail fossil found in the BL unit support this interpretation. $\mathrm{Ca}^{2+}$ is a mobile cation that likely resides in calcite for the samples in this study. Because calcite is easily removed and/or added to the system, it is therefore not a reliable proxy for the original composition of the footprint site samples. Evidence for interaction between the LFL, BL, and MRL with the calcitesaturated alkaline lake waters of Lake Natron or spring/surface waters is present in CL images showing rinds of calcite on surfaces and within pore spaces (Fig. 7b), and in the carbon and oxygen isotope values (Fig. 10c).

If the stable isotopic values of the LFL and MRL had both been overprinted by modern (meteoric) water flowing through the region, the $\delta^{18} 0$ values for both units should be similar. However, the stable isotopic values of the LFL and MRL are distinctive (Fig. 10c). In line with reported temperatures for nearby surface waters (Table 1), the range in isotopic values for the LFL indicate precipitation of calcite in pore fillings that is in equilibrium with water that has a $\delta^{18} \mathrm{O}_{\mathrm{w}}$ value of $-2.5 \%$ SMOW (Bowen et al., 2010; Coplen et al., 1983) at $\sim 23^{\circ} \mathrm{C}$, and a DIC $\delta^{13} \mathrm{C}$ value of 4.2\%o (using $\alpha=1.00197$ for temperature-dependent precipitation of calcite from solution at $25^{\circ} \mathrm{C}$ )(Deines et al., 1974). This suggests a freshwater (low $\delta^{18} \mathrm{O}_{\mathrm{w}}$ ), rather than saline, source. The $\delta^{18} \mathrm{O}$ and $\delta^{13} \mathrm{C}$ values recorded in the LFL are similar to those reported by Hillaire-Marcel et al. (1986) for travertine $\left(\mathrm{CaCO}_{3}\right)$ measured at Engare Sero $\left(\delta^{18} \mathrm{O}=-5 \%\right.$ o PD, and $\delta^{13} \mathrm{C}=-2.8 \%$ oDB $)$. They report that modern springwater in the Oldoinyo L'engai region has a $\delta^{13} \mathrm{C}$ value for dissolved inorganic carbon (DIC) of $-4.6 \%$ PDB; therefore, their measured values for travertine appear to be 
in approximate equilibrium with water and DIC (Hillaire-Marcel et al., 1986). $\delta^{13} \mathrm{C}$ values for both the LFL and MRL are within the range of $\delta^{13} \mathrm{C}$ values reported for calcite within altered lavas and tuffs from Oldoinyo L'engai (-7.6 to 0.7\%o PDB; Hay, 1989) and local travertine measured by Hillaire-Marcel et al. (1986).

The difference in the $\delta^{13} \mathrm{C}$ values for the LFL and MRL (Fig. 10c) may indicate that the water that precipitated the calcite in the MRL had more time to equilibrate with atmospheric $\mathrm{CO}_{2}$ than the water that precipitated the calcite in the LFL (Hillaire-Marcel et al., 1986). Likewise, higher $\delta^{180}$ values for the MRL most likely represent precipitation of calcite from more evaporative waters (with a higher $\delta^{18} \mathrm{O}_{\mathrm{w}}$ ), as equilibrium precipitation of $\delta^{18} \mathrm{O}_{\text {calcite }}$ values of the MRL from either meteoric $\left(\delta^{18} \mathrm{O}_{\mathrm{w}}=-2.5 \% \mathrm{SMOW}\right)$ or spring waters $\left(\delta^{18} \mathrm{O}_{\mathrm{w}}=-4.5 \% \mathrm{SMOW}\right)$ would require unrealistically low water temperatures for the region, at $<4^{\circ} \mathrm{C}$ (per Coplen et al., 1983). Waters from Lake Natron would have higher $\delta^{18} 0$ and $\delta^{13} \mathrm{C}$ values than local spring water or groundwater (Hillaire-Marcel et al., 1986), due to evaporation and isotopic exchange with atmospheric $\mathrm{CO}_{2}$, and therefore the source of the calcite in the MRL seems to have been saline, alkaline lake water during a subsequent high stand of paleo-Lake Natron. Hillaire-Marcel et al. (1986) propose a lake highstand at 10-12 ka, which could have inundated the footprint site. XRD analysis of the MRL indicates an abundance of phillipsite-K, which supports the interpretation that the MRL interacted with saline, alkaline lake waters during a subsequent lake transgression.

\subsection{Method of Emplacement}

The presence of flow ridges and extremely large cobbles in the BL unit suggest a highdensity debris flow as the deposition mechanism. Mudcracks on the surface of all layers (where exposed) indicate a saturated deposit and subsequent desiccation. The BL unit is the only layer 
where the top and bottom are identifiable in outcrop, however the actual volume and thickness of the original debris flow is unknown, as the bulk of it may have been eroded away leaving only the larger blocks, block impressions, and residual sediments behind. The BL thins to the north (presumably the lateral edge of the flow) and onlaps the hummocks of the YTA (per Dawson, 1959; the "zebra debris avalanche" per Kervyn et al., 2008), indicating that the YTA was already emplaced at the time of the BL debris flow. Interspersed thin layers of mud between the LFL and BL suggest a period of quiescence and possible lacustrine or spring inundation between depositional events.

A recent publication by Balashova et al. (2016) divides the sequence at Engare Sero into two units: FTa (our LFL and BL) overlain by FTb (our MRL). They interpret the MRL as reworked LFL sediments that incorporated wind-blown biotite, largely based on observations of abraded edges of biotite crystals, which they attribute to damage incurred during aeolian transport. Our data, however, support the interpretation that the MRL was fluvially emplaced. (1) Geochemical analysis and petrologic observations of the LFL and MRL indicate that the two units are both geochemically and mineralogically distinct (Fig. 10, Table S2), so that the MRL is unlikely to be a mixture of LFL sediments and wind-blown biotite. Balashova et al. (2016, their Figure 6) show compositional data from pyroxene and nepheline that further support the idea that the LFL and MRL are geochemically distinct and derived from different eruptions. (2) Analysis of the grain size distribution of the MRL (sampled directly above the human footprints) shows that the deposit is poorly sorted and coarseskewed (Fig. 6b). Coarse-skewed sediment samples contain excess poorly sorted coarse grains, which is unlikely with aeolian deposits given that wind has a lower competency than water (Vessell and Davies, 1981; de Bélizal et al., 2013). Our grain size data indicate, therefore, that water rather than wind likely transported the MRL. (3) Silt embedded within the cleavage of the MRL supports the hypothesis that this deposit was reworked by water. We interpret the slightly abraded edges of biotite crystals as damage incurred during fluvial transport. 
We propose that the source of the MRL was the Qol lahar deposits reported by Sherrod et al. (2013) on the northern flanks of Oldoinyo L'engai. These lahar deposits are texturally and minerologically similar to the MRL (Fig. 10b), containing large flakes of biotite in a finer-grained matrix. We interpret the MRL as the result of fluvial remobilization of the Qol deposits, since drainage off Oldoinyo L'engai enters the Engare Sero River channel and then flows to the footprint site. Given the fragility of 3-cm-biotite crystals in a fluvial environment, and the lack of large biotites in other fluvial deposits in the Engare Sero area, we suggest the MRL was likely reworked soon after the emplacement of the Qol deposits. Some or all of the embedded silt and edge damage may have developed during laharic transport, prior to fluvial reworking.

\subsection{Timing of Footprint Emplacement}

We propose that sometime before the humans (and animals) walked through the area, nepheline-rich, fine-grained material previously erupted from Oldoinyo L'engai was deposited on the shore of Lake Natron, creating the LFL unit. The overlying mud layers, plant fragments, and plant/thorn impressions indicate a subsequent aquatic environment (possibly emergence of a freshwater marsh, as suggested by the low $\delta^{18} \mathrm{O}$ values of calcite within the LFL). A debris flow later remobilized a cobble-rich deposit either from the slopes of Oldoinyo L'engai or from the Engare Sero River canyon. These volcaniclastic sediments followed the path of the Engare Sero River channel, traveling N/NE towards the shore of Lake Natron, and onlapped the pre-existing topographic highs of YTA. The poorly sorted nature of the BL unit (including clasts up to $1 \mathrm{~m}$ in diameter) and the presence of flow indicators (i.e., ridges formed on the surface of the deposit) suggest that the flow was high density with large cobbles and boulders being transported $>10 \mathrm{~km}$ from the source. The composition of the cobbles (i.e., phonolite, vesicular basalt, etc.) indicates that Oldoinyo L'engai is not the source of the actual cobbles-- instead the debris flow incorporated 
various lithologies, including basement basalt, various lava flows, etc., along its path. This cobblerich flow remained wet and pliable after deposition, long enough for plant leaves and both land and aquatic snails to be incorporated, as it is unlikely that the intact leaves and delicate gastropods could be transported by the debris flow without being damaged. The pre-existing, large hummocks of YTA kept the BL debris flow contained to the south (it did not enter the lake, at least at the footprint site), and the BL unit may not have been deposited (or only thinly deposited) in the area around the human footprints. Sometime after the BL sediments were deposited and while the BL sediments were wet (either prior to desiccation or after being rewet, creating a pliable substrate), a group of zebras walked through this mix of damp volcaniclastic sediments, creating impressions in the BL and the underlying (either not yet lithified or rewetted and remobilized) LFL unit. The humans and bovids remained on the edge of the flow, closer to the topographic high of the YTA, and made their trackways in the wet sediments of the pliable BL and LFL. Since little BL unit sediments were present at this distal edge of the flow, the human footprints are pressed into LFL sediments but some rare, small pebbles are associated with the human prints. As these units dried, the desiccation cracks formed and the footprints were preserved in the hardened sediments. It is difficult to speculate why the humans and animals might have been in this area, but given the aridity of the region they may have been accessing the food and water resources associated with the fresh water source (wetland?) that emerged after emplacement of the LFL.

The long-term preservation of the human and animal footprints is a direct result of the deposition of the overlying mica rich layer (the MRL). Lab experiments indicate that any impressions made in damp volcaniclastic debris of similar composition (collected from the flanks of Oldoinyo L'engai) are preserved once the substrate dries, but are destroyed if the sediment becomes wet again by rainfall or gradual inundation (similar to the results reported by Scott et al., 2010). Therefore, had the footprinted LFL and BL units become wet after the impressions were made, the impressions would have deteriorated and/or been destroyed. Thus, the preservation of 
these footprints requires burial and the age of the overlying MRL best constrains the youngest age of the footprints. The MRL would have to have been deposited after the humans, zebras, and bovids walked through the wet LFL/BL units and before the surface was rewetted by meteoric or surface water. This leaves a window of potentially a few hours to a few days or months (i.e., the length of the dry season), depending on the timing and magnitude of rainfall events, for the prints to be made and then preserved beneath the MRL unit. The MRL was inundated with saline lake water sometime after it was deposited, further constraining the deposition of that unit to before the 10-12 ka highstand of Lake Natron (Hillaire-Marcel et al., 1986). A recent publication (Balashova et al., 2016) proposed a Holocene age for the Engare Sero footprints. Our radioisotopic dating suggests an age between a minimum of $5760 \pm 30 \mathrm{yrs} B P$ and a maximum of $19.1 \pm 3.1 \mathrm{ka}$. The prints must certainly also predate the highstand of Lake Natron that produced the calcite cement in the MRL (10-12 ka), pointing to a latest Pleistocene age for the formation of the Engare Sero footprints.

\section{Significance and Conclusions}

Fossil evidence shows that early modern Homo sapiens were present in eastern Africa by ca. 200 ka (White et al., 2003; McDougall et al., 2005). The Engare Sero footprint site contains trace fossils of modern humans and with over 400 human prints uncovered thus far, and likely more buried underneath the northern sand dunes, it is currently the most abundant late Pleistocene $H$. sapiens footprint site in Africa. The site is unique in that it has the potential to shed light on human behavior in the latest Pleistocene as well as provide evidence of human interaction with the dynamic (and potentially hazardous?) nature of the volcanically influenced shoreline of Lake Natron at this time. By knowing the volcanic source as well as inferring physical and behavioral characteristics about the makers of the footprints (e.g., Richmond et al., 2011; Hatala et al., 2012), it is possible to piece together the landscape and overall environment of the Engare Sero region. This 
environment certainly supported, yet challenged, anatomically modern humans-providing potential food and water sources amidst a volcanically active and dynamic landscape.

\section{Acknowledgements}

The research presented here was funded by the National Geographic Society's Committee for Research and Exploration, the National Science Foundation (NSF BCS-1128170), the Leakey Foundation, Appalachian State University (the University Research Council, the Office of International Education and Development, and the Office of Student Research), the George Washington University, the Evolving Earth Foundation, the Smithsonian Institution's Human Origins Program, and the Pennsylvania Institute for Conservation Education. We sincerely thank the Tanzanian Commission on Science and Technology, the Department of Antiquities and their representatives (Donatius Kamamba, Felix Ndunguru, Godfrey Olle Moita, Christowaja Ntandu, and Neema Mbwana), and the Ministry of Natural Resources and Tourism (Permanent Secretary Dr. Ladislaus Komba) for their continued assistance and permission to conduct research at Engare Sero since 2009 (COSTECH permit \#2011-89-ER-2009-75). Kongo Sakkae, of the Engare Sero Village, is credited with discovering this site prior to 2006, while Julian von Mutius and Gerald Gwau were instrumental in bringing this site to the attention of the scientific community. Tim Leach and the staff of the Lake Natron Tented Camp are warmly thanked for their commitment to this project as well as their accommodation, as are Ndashy Munuo and the residents of the Engare Sero Village. Good Earth Tours and Global Rescue provided field support. NSF Grant EAR-1322017 supported dating efforts at the BGC. The authors would also like to thank the following individuals for their assistance: Dr. Jörg Keller, Dr. James D. Wright, Dr. Craig Feibel, Dr. Henning Scholz, Dr. Bert Van Bocxlaer, Dr. Kate Scharer, Dr. Scott Marshall, Steven Davis, Katie Wolf, Dr. Nelia Dunbar, Dr. Richard Abbott, Anthony Love, Dr. Johnny Waters, Barbara Waters, Carol Liutkus, and Dr. Michael 
Manyak. This paper has been significantly improved through the efforts of two anonymous reviewers. 


\section{Figure Captions}

Figure 1. Position of the footprint sites within the Engare Sero region. The East African Rift escarpment runs North-South along the left side of the map. The Engare Sero footprint site sits to the south of Lake Natron (denoted by the red box, which is enlarged below.) Smaller volcanic centers analyzed as part of this study are labeled. Base map for enlargement from Google Earth.

Figure 2. Overview of human footprint site at Engare Sero, looking south towards Oldoinyo L'engai. The broad, flat region in which the footprints sit is an ephemeral channel of the Engare Sero River that drains the East African Rift scarp (right) towards the modern shore of Lake Natron (to the north). The footprint trackways trend NE-SW and the footprinted surface (LFL in this image) exhibits large polygonal desiccation cracks as well as erosional channels.

Figure 3. Generalized stratigraphic column of units associated with the Engare Sero footprints.

Figure 4. Features of the LFL. (a) When preserved in stratigraphic contact, the LFL is separated from the overlying BL unit by a thin mud layer $(<1 \mathrm{~cm})$. (b) The mud layer covering the $\mathrm{LFL}$, exhibiting root holes and impressions of plant stems. (c) Plant fragment found adjacent to the human footprints, and (d) thorn impression (possibly from Acacia) in the LFL.

Figure 5. Features of the BL, including (a) a large vesicular basalt boulder in the BL matrix (scale shows $\sim 80 \mathrm{~cm}$ diameter), (b) flow ridges indicating a high-density flow, (c) desiccation cracks, (d) exquisitely preserved leaf (with small volcanic pebble at top), and (e) aquatic gastropod fossil, identified as Melanoides $c f$. tuberculata (Van Bocxlaer, B., pers. comm.; Scholz, H., pers. comm.).

Figure 6. The MRL sits on top of the BL (a) and is distinctive because of its large (up to $3 \mathrm{~cm}$ diameter) mica flakes. Grain size distribution within the MRL (b) shows that coarse grain sizes are poorly sorted, indicating a coarse-skewed (and more likely fluvially-deposited) unit. Data on the xaxis $(\mathrm{N}=1065$ grains $)$ ranged from a minimum grain area of $0.01 \mathrm{~mm}^{2}$ to a maximum of $0.3 \mathrm{~mm}^{2}$, 
but data are only shown up to $0.1 \mathrm{~mm}^{2}$ (to illustrate the pattern effectively). There were 30 additional grains detected that were larger than $0.1 \mathrm{~mm}^{2}$ (off scale). (c) Image of MRL used to process grain size distribution; PPL.

Figure 7. (a) Thin-section microscopy image of the LFL, showing crystals of nepheline (Ne) and augite (Au), PPL. (b) Cathodoluminescence microscopy image of BL, indicating secondary carbonate (red) infilling voids. (c) Thin-section microscopy image of the MRL, showing very large crystals of biotite (Bi) and smaller nepheline (Ne), PPL.

Figure 8. Backscattered electron microprobe images of biotite from the MRL. (a) Clay and/or silt within cleavage of biotite grain from sample CML-ES-13-005. (b) Close up of same. (c) Apparently pristine cleavage face of slice of crystal FPB-1 (left grain). (d) Clay between cleavages along grain margin of FPB-1 (rotated to show grain margin). (e) Apparently pristine cleavage face slice of crystal FPB-2. (f) Clay-free grain margin of FBP-2 (rotated to show grain margin).

Figure 9. Plot of $\mathrm{SiO}_{2}$ versus $\mathrm{FeO}$ for microprobe analyses on slices of dated biotite crystals from sample CML-ES-13-005 (from MRL unit).

Figure 10. Chemical composition of various volcanic and footprint-site samples obtained from the Engare Sero region. (a) Magmatic classification after Winchester and Floyd, 1977. (b) Geochemical composition of volcanic samples from Engare Sero region, plotted as weight $\% \mathrm{MgO} v \mathrm{vs} \mathrm{Al}_{2} \mathrm{O}_{3}+$ $\mathrm{Fe}_{2} \mathrm{O}_{3}$, showing similarities between the footprinted site samples and previous Oldoinyo L'engai eruptions (OL-104). (c) Stable oxygen and carbon isotope composition of LFL and MRL samples, VPDB. Shaded region indicates $\delta^{18} \mathrm{O}$ values of calcite precipitated in equilibrium with meteoric water at $\sim 22^{\circ} \mathrm{C}\left(\delta^{18} \mathrm{Ow}=-2.5 \%\right.$ VSMOW, per Bowen 2016).

Figure 11. Age probability distribution of 15 biotite grains from sample Bio-MicaTuff (an MRL sample) analyzed by Berkeley Geochronology Center, showing a principal mode at $19.1 \pm 3.1$ 
ka. Solid line shows probability distribution of youngest four crystals. Dashed line shows probability distribution of all analyzed crystals.

Figure 12. Age-probability plot of plateau ages from 20 analyses of 15 biotite crystals from sample CML-ES-13-005 from the MRL, analyzed by New Mexico Geochronology Research Laboratory, showing youngest mode at $48 \pm 8 \mathrm{ka}$. Solid line shows probability distribution of youngest six crystals. Dashed line shows probability distribution of all analyzed crystals. 


\section{Table Captions}

Table 1. Chemistry of fluid solutions reacted with modern ash in footprint-stability experiments. Solution chemistries were modeled after data presented in Deocampo (2002) and Warren (2006).

Table 2. Mineralogy confirmed by XRD, SEM-EDS, or optical microscopy for footprint site samples and OL-104 (from Oldoinyo L'engai).

Table 3. Age dating methods employed for various units at the footprint site. 


\section{References}

Ashley, G.M., and Liutkus, C.M., 2002, Tracks, trails, and trampling by large vertebrates in a rift valley paleo-wetland, lowermost Bed II, Olduvai Gorge, Tanzania: Ichnos, v. 9, p. 23-32.

Balashova, A., Mattsson, H.B., Hirt, A.M., and Almqvist, B.S.G., 2016, The Lake Natron Footprint Tuff (northern Tanzania): volcanic source, depositional processes and age constraints from field relations: Journal of Quaternary Science, v. 31, p. 526-537.

Bennett, M.R., Harris, J.W.K., Richmond, B.G., Braun, D.R., Mbua, E., Kiura, P., Olago, D., Kibunjia, M., Omuombo, C., Behrensmeyer, A.K., Huddart, D., and Gonzalez, S., 2009, Early hominin foot morphology based on 1.5 million year-old footprints from Ileret, Kenya: Science v. 323, p. 11971201.

Bennett, M.R., Morse, S.A., Liutkus-Pierce, C., McClymont, J., Evans, M., Crompton, R.H., and Thackeray, J.F., 2014, Exceptional preservation of children's footprints from a Holocene footprint site in Namibia: Journal of African Earth Sciences, v. 97, p. 331-341.

Bennett, M.R., and Morse, S.A., 2014, Human Footprints: Fossilized Locomotion? Springer International Publishing, New York, NY, 216 p.

Bowen, G. J., 2016, The Online Isotopes in Precipitation Calculator, version 2.2. http://www.waterisotopes.org.

Bowen, G. J. and Revenaugh J., 2003, Interpolating the isotopic composition of modern meteoric precipitation. Water Resources Research, v. 39, n.10, 1299, doi:10.129/2003WR002086.

Cerling, T.E., and Quade, J., 1993, Stable carbon and oxygen isotopes in soil carbonates: in Climate Change in Continental Isotope Records (Swart, P.K, Lohmann, K.C. McKenzie, J.A., and Savin, S., eds), American Geophysical Union Publication no. 78, p. 217-239. 
Chappell, J. and Polach, H.A., 1972, Some effects of partial recrystallization on ${ }^{14} \mathrm{C}$ dating late Pleistocene corals and molluscs: Quaternary Research, v. 2, p. 244-252.

Cohen, A., Lockley, M., Halfpenny, J, and Michel, A.E., 1991, Modern vertebrate track taphonomy at Lake Manyara, Tanzania: Palaios, v. 6, p. 371-389.

Coplen, T.B., Kendall, C., and Hopple, J., 1983, Comparison of stable isotope reference samples: Nature, v. 302, p. 236-238.

Craig, H., 1965, The measurements of oxygen isotope paleotemperatures: in Stable Isotopes in Oceanographic Studies and Paleotemperatures (Tongiorgi, E., ed), Consiglio Nazionale delle Richerche, 1-24.

Crompton, R.H., Pataky, T.C., Savage, R., D'Août, K., Bennett, M.R., Day, M.H., Bates, K., Morse, S., Sellers, W.I., 2012, Human-like external function of the foot, and fully upright gait, confirmed in the 3.66 million year old Laetoli hominin footprints by topographic statistics, experimental footprintformation and computer simulation: Journal of the Royal Society Interface, v. 9, p. 707-719.

Cuthbert, M.O., and Ashley, G.M., A spring forward for hominin evolution in East Africa: PLoS ONE, v. 9, e107358. doi:10.1371/journal.pone.0107358

Day, M.H., Wickens, E.H., 1980, Laetoli Pliocene hominid footprints and bipedalism: Nature, v. 286, p. 385-387.

Dawson, J.B., 1962, The geology of Oldoinyo Lengai: Bulletin of Volcanology, v. 24, p.349-387.

Dawson, J.B., 2008, The Gregory Rift Valley and Neogene-Recent Volcanoes of Northern Tanzania: Geological Society of London Memoir No. 33, 102 pp.

Dawson, J.B. and Powell, D.G., (1969) The Natron-Engaruka explosion crater area, northern Tanzania: Bulletin of Volcanology, v. 33, p. 791-817. 
de Belizal, E., Lavigne, F.S., Hadmoko, D., Degeai, J-P., Dipayana, G.A., Mutaqin, B.W., Marfai, M.A., Coquet, M., Le Mauff, B., Robin, A-K., Vidal, C., Cholik, N., and Aisyah, N., 2013, Rain-triggered lahars following the 2010 eruption of Merapi volcano, Indonesia: A major risk: Journal of Volcanology and Geothermal Research, v. 261, p. 330-347.

Deines, P., Langmuir, D., and Harmon, R.S., 1974, Stable carbon isotope ratios and the existence of a gas phase in the evolution of carbonate ground waters: Geochimica et Coscochimica Acta, v. 38, p. 1147-1164.

Deino, A.L., Scott, G.R., Saylor, B., Alene, M., Angelini, J.D., and Haile-Selassie, Y., 2010, ${ }^{40} \mathrm{Ar} /{ }^{39} \mathrm{Ar}$ dating, paleomagnetism, and tephrochemistry of Pliocene strata of the hominid-bearing WoransoMille area, West-Central Afar Rift, Ethiopia: Journal of Human Evolution, v. 58, p. 111-126.

Deocampo, D.M., 2002, Sedimentary structures generated by Hippopotamus amphibius in a lakemargin wetland, Ngorongoro Crater, Tanzania: Palaios, v. 17, p. 212-217.

Deocampo, D.M., 2004, Authigenic clays in East Africa: Regional trends and paleolimnology at the Plio-Pleistocene boundary, Olduvai Gorge, Tanzania: Journal of Paleolimnology, v. 31, p. 1-9.

Dingwall, H.L., Hatala, K.G., Wunderlich, R.E., and Richmond, B.G., 2013, Hominin stature, body mass, and walking speed estimates based on 1.5 million-year-old fossil footprints at Ileret, Kenya: Journal of Human Evolution, v. 64, p. 556-568.

Duday, H., Garcia, M.-A., 1983, Les empreintes de l'homme préhistorique. La grotte du Pech-Merle à Cabrerets (Lot), une relecture significative des traces de pieds humains: Bulletin de la Société préhistorique française. 80, 208-215.

Fisher, R.V., and Schmincke, H-U., 1984, Pyroclastic Rocks: Springer-Verlag, 472 pp. 
Hatala, K.G., Richmond, B.G., Harcourt-Smith, W.E.H., Liutkus, C.M., Zimmer, B., 2012, A snapshot of the anatomy, locomotion, and social behavior of early modern humans as evidenced by fossil footprints at Engare Sero, Tanzania: Journal of Vertebrate Paleontology, Supplement, v. 72, p. 107.

Hatala, K.G., Dingwall, H.L., Wunderlich, R.E., and Richmond, B.G., 2013, The relationship between plantar pressure and footprint shape: Journal of Human Evolution, v. 65, p. 21-28.

Hatala, K.G., Wunderlich, R.E., Dingwall, H.L., Richmond, B.G., 2016, Interpreting locomotor biomechanics from the morphology of human footprints: Journal of Human Evolution, v. 90, p. 3848.

Hay, R.L., 1986, Role of tephra in the preservation of fossils in Cenozoic deposits of East Africa: in Geological Society of London Special Publication no. 25, p. 339-344.

Hay, R.L., 1987, Geology of the Laetoli area, in: Leakey, M.D., Harris, J.M. (Eds.), Laetoli: a Pliocene site in northern Tanzania: Clarendon Press, Oxford, pp. 23-61.

Hay, R.L., 1989, Holocene carbonatite-nephelinite tephra deposits of Oldoinyo L'engai, Tanzania: Journal of Volcanology and Geothermal Research, v. 37, p. 77-91.

Heiken, G., and Wohletz, K., 1985, Volcanic Ash: University of California Press, 256 pp.

Hillaire-Marcel, C., Carro, O., and Casanova, J., 1986, ${ }^{14} \mathrm{C}$ and Th/U dating of Pleistocene and Holocene stromatolites from East African paleolakes: Quaternary Research, v. 25, p. 312-329.

Hillaire-Marcel, C., Casanova, J., and Taieb, M., 1987, Isotopic age and lacustrine environments during Late Quaternary in the Tanzanian rift (Lake Natron), In Rampino, M.R., Sanders, J.E., Newman, W.S., and Koningsson, L.K., (eds.), Climate: history, periodicity, and predictability: New York, Van Nostrand Reinhold Co., p. 117-123. 
Klaudius, J. and Keller, J., 2006, Peralkaline silicate lavas at Oldoinyo Lengai, Tanzania: Lithos, v. 91, p. 173-190.

Kervyn, M., Ernst, G.G.J., Klaudius, J., Keller, J., Mbede, E., and Jacobs, P., 2008, Remote sensing study of sector collapses and debris avalanche deposits at Oldoinyo Lengai and Kerimasi volcanoes, Tanzania: International Journal of Remote Sensing, v. 29, n. 22, p. 6565-6595.

Kuiper, K.F., Deino, A., Hilgen, F.J., Krijgsman, W., Renne, P.R., and Wijbrans, J.R., 2008, Synchronizing rock clocks of Earth history: Science, v. 320, p. 500-504.

Laporte, L.F., and Behrensmeyer, A.K., 1980, Tracks and substrate reworking by terrestrial vertebrates in Quaternary sediments of Kenya: Journal of Sedimentary Petrology, v. 50, p. 13371346.

Leakey, M.D., and Hay, R.L., 1979, Pliocene footprints in the Laetolil Beds at Laetoli, northern Tanzania: Nature, v. 278, p. 317-323.

Lee, J.-Y., Marti, K., Severinghaus, J.P., Kawamura, K., Yoo, H.-S., Lee, J.B., and Kim, J.S., 2006, A redetermination of the isotopic abundances of atmospheric Ar: Geochimica et Cosmochimica Acta, v. 70, p. $4507-4512$.

Leng, M. J., Lamb, A.L., Lamb, H.F., and Telford, R.J., 1999, Paleoclimatic implications of isotopic data from modern and early Holocene shells of the freshwater snail Melanoides tuberculata, from lakes in the Ethiopian Rift Valley: Journal of Paleolimnology, v. 21, p. 97-106.

Mana, S., Furman, T., Carr, M.J., Mollel, G.F., Mortlock, R.A., Feigenson, M.D., Turrin, B.D., and Swisher III, C.C., 2012, Geochronology and geochemistry of the Essimingor volcano: Melting of metasomatized lithospheric mantle beneath the North Tanzanian Divergence zone (East African Rift): Lithos, v. 155, p. 310-325. 
McDougall, I., and Harrison, T.M., 1999, Geochronology and Thermochronology by the ${ }^{40} \mathrm{Ar} /{ }^{39} \mathrm{Ar}$ Method: Oxford University Press, New York, NY, 269 pp.

McDougall, I., Brown, F.H., and Fleagle, J.G., 2005, Stratigraphic placement and age of modern humans from Kibish, Ethiopia: Nature, v. 433, p. 733-736.

Morse, S.A., Bennett, M.A., Liutkus-Pierce, C., Thackeray, F., McClymont, J., Savage, R., and Crompton, R.H., 2013, Holocene footprints in Namibia: The influence of substrate on footprint variability: American Journal of Physical Anthropology, v. 151, p. 265-279.

Pastoors, A., Lenssen-Erz, T., Breuckmann, B., Ciqae, T., Kxunta, U., Rieke-Zapp, D., Thao, T., 2016 (in press), Experience based reading of Pleistocene human footprints in Pech-Merle: Quaternary International.

Raichlen, D.A., Pontzer, H., and Sockol, M.D., 2008, The Laetoli footprints and early hominin locomotor kinematics: Journal of Human Evolution, v. 54, p. 112-117.

Raichlen, D.A., Gordon, A.D., Harcourt-Smith, W.E., Foster, A.D., Haas, W.R., 2010, Laetoli footprints preserve earliest direct evidence of human-like bipedal biomechanics: PLoS One, v. 5, e9769.

Renne, P.R., Swisher, C.C., Deino, A.L., Karner, D.B., Owens, T. L., and DePaolo, D. J., 1998, Intercalibration of standards, absolute ages, and uncertainties in Ar-40/Ar-39 dating: Chemical Geology, v. 145, p. 117-152.

Richmond, B.G., Hatala, K.G., Harcourt-Smith, W.E.H., Rossi, V., Metallo, A., Liutkus, C.M., Pobiner, B.L., Gordon, A.D., Dingwall, H.L., Green, D.J., Olle Moita, G., Brett, J., 2011, Early modern human footprint assemblage from Engare Sero, Tanzania: Paleoanthropology, v. 2011, p. A31. 
Roach, N.T., Hatala, K.G., Ostrofsky, K.R., Villmoare, B.A., Reeves, J., Du, A., Braun, D.R., Harris, J.W.K., Behrensmeyer, A.K., Richmond, B.G., 2016, Pleistocene footprints reveal intensive use of lake margin habitats by Homo erectus groups: Scientific Reports, v. 6, article number 26374.

Scholz, H., personal communication via email, 2010.

Scott, J.J., Renaut, R.W., and Owen, R. B., Taphonomic controls on animal tracks at saline, alkaline Lake Borogia, Kenya Rift Valley: Impact of salt efflorescence and clay mineralogy: Journal of Sedimentary Research, v. 80, p. 639-665.

Sherrod, D.R., Magigita, M.M., and Kwelwa, S., 2013, Geologic map of Oldonyo Lengai (Oldoinyo Lengai) volcano and surroundings, Arusha region, United Republic of Tanzania: United States Geological Survey, Open-File Report 2013-1306, pamphlet to accompany map 65, scale 1:50,000 [http://dx.doi.org/10.3133/ofr20131306].

Siggurdson, H., 1999, Fallout deposits In: Houghton, B., Rymer, H., Stix, J., McNutt, S., and Sigurdsson, H., Encyclopedia of Volcanoes: Academic Press, 1417 pp.

Smith, G.A., and Katzman, D., 1991, Discrimination of eolian and pyroclastic-surge processes in the generation of cross-bedded tuffs, Jemez Mountains volcanic field, New Mexico: Geology, v. 19, p. $465-468$.

Stollhofen, H., Stainstreet, I.G., McHenry, L.J., Mollel, G.F., Blumenschine, R.J., Masao, F.T., 2008, Fingerprinting facies of the tuff IF marker, with implications for early hominin palaeocology, Olduvai Gorge, Tanzania: Palaeogeography, Palaeoclimatology, Palaeoecology, v. 259, p. 382-409.

Stuiver, M., and Polach, H.A., 1977, Discussion: Reporting of ${ }^{14} \mathrm{C}$ data: Radiocarbon, v. 19, n. 3., p. $355-363$.

Trauth, M., 2010, MATLAB Recipes for Earth Sciences (3 ${ }^{\text {rd }}$ Edition): Springer, New York, NY, 336pp. 
Tuttle, R., Webb, D., Weidl, E., Baksh, M., 1990, Further progress on the Laetoli trails: Journal of Archaeological Science, v. 17, p. 347-362.

Van Bocxlaer, B., personal communication via email, 2010.

Vita-Finzi, F., and Roberts, N., 1984, Selective leaching of shells for ${ }^{14} \mathrm{C}$ dating: Radiocarbon, v. 26, p. 54-58.

Vessell, R.K., and Davies, D.K., 1981, Nonmarine sedimentation in an active forearc basin, In Ethridge, F.G., and Flores, R.M., (eds.), Recent and Ancient Non-marine Environments: SEPM Special Publication 31, p. 31-45.

Warren, J.K., 2006, Evaporites: Sediments, Resources, and Hydrocarbons: Springer, New York, NY, $1041 \mathrm{pp}$.

White, T.D., Asfaw, B., DeGusta, D., Gilbert, H., Richards, G.D., Suwa, G., Howell, F.C., 2003, Pleistocene Homo sapiens from Middle Awash, Ethiopia: Nature, v. 423, p. 742-7.

Winchester, J. A., and Floyd, P. A., 1977, Geochemical discrimination of different magma series and their differentiation products using immobile elements: Chemical Geology, v. 20, p. 325-343. 
FPgére
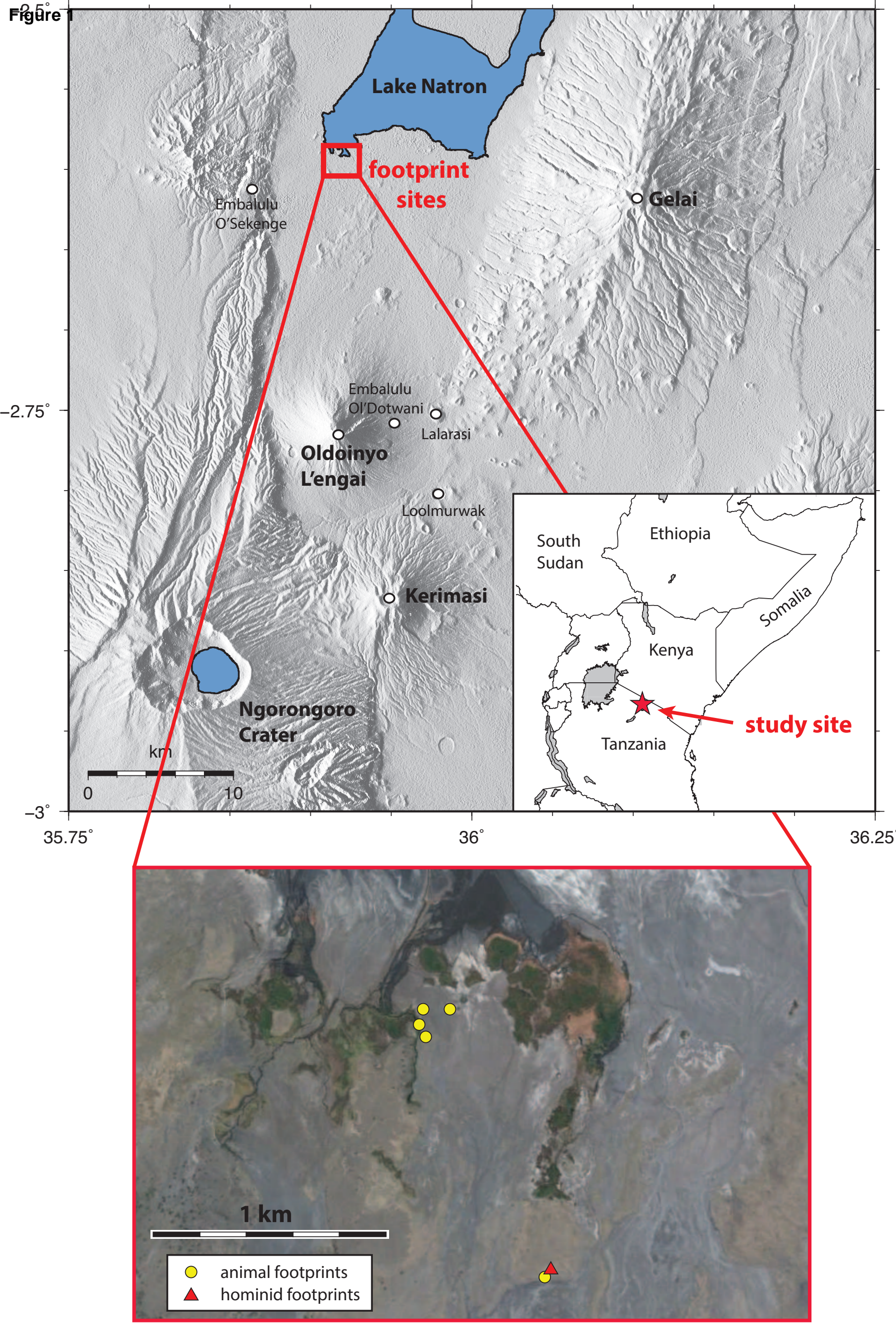
SW

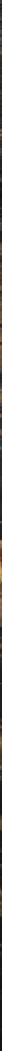

\section{Liutkus et al., Figure 2}

Figure 2

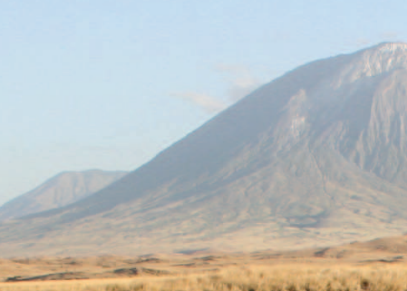

(

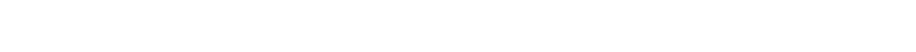

$+2$

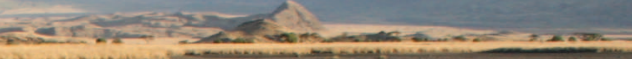

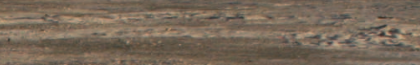




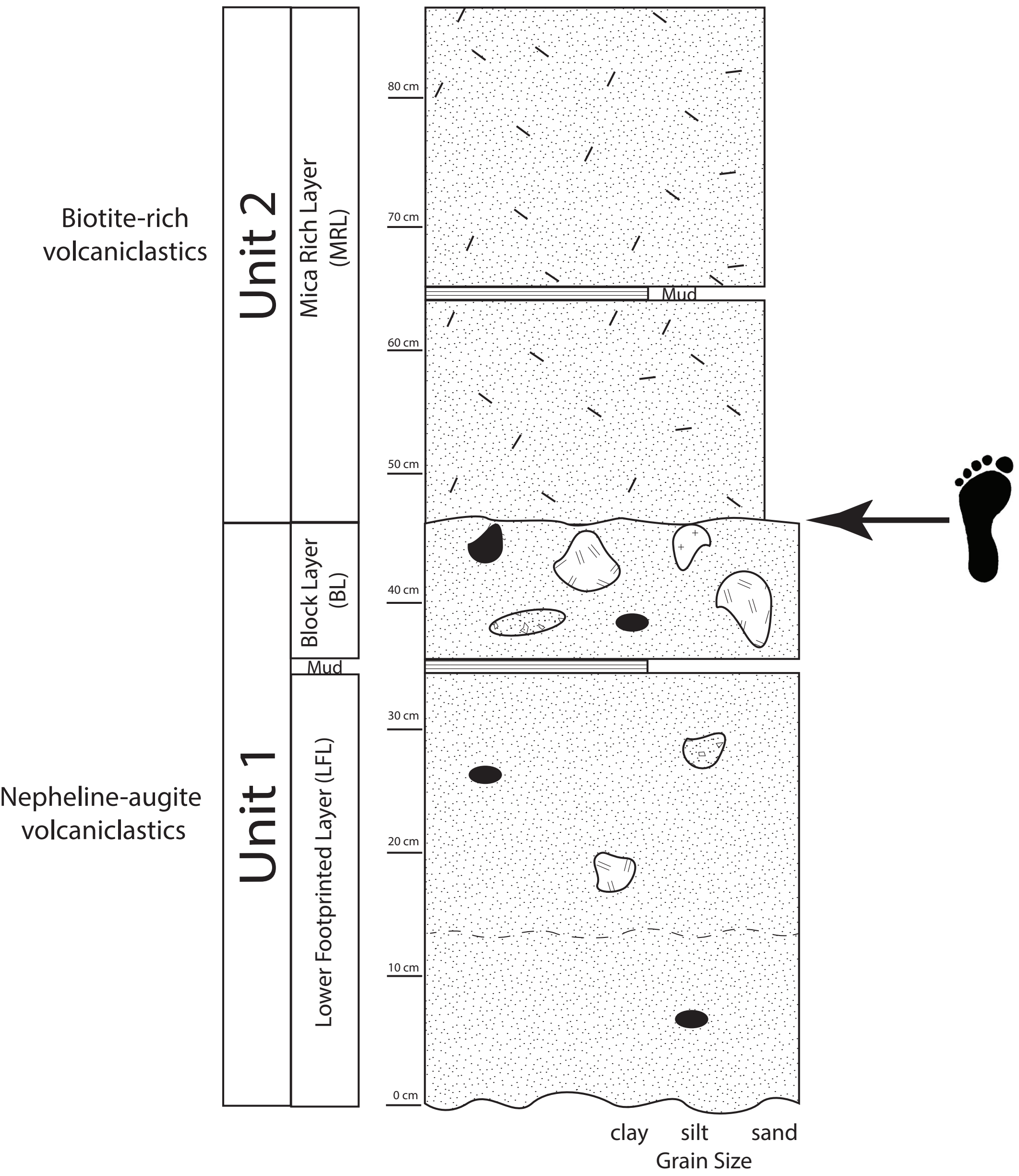



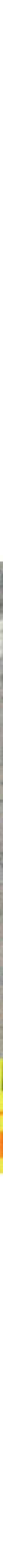

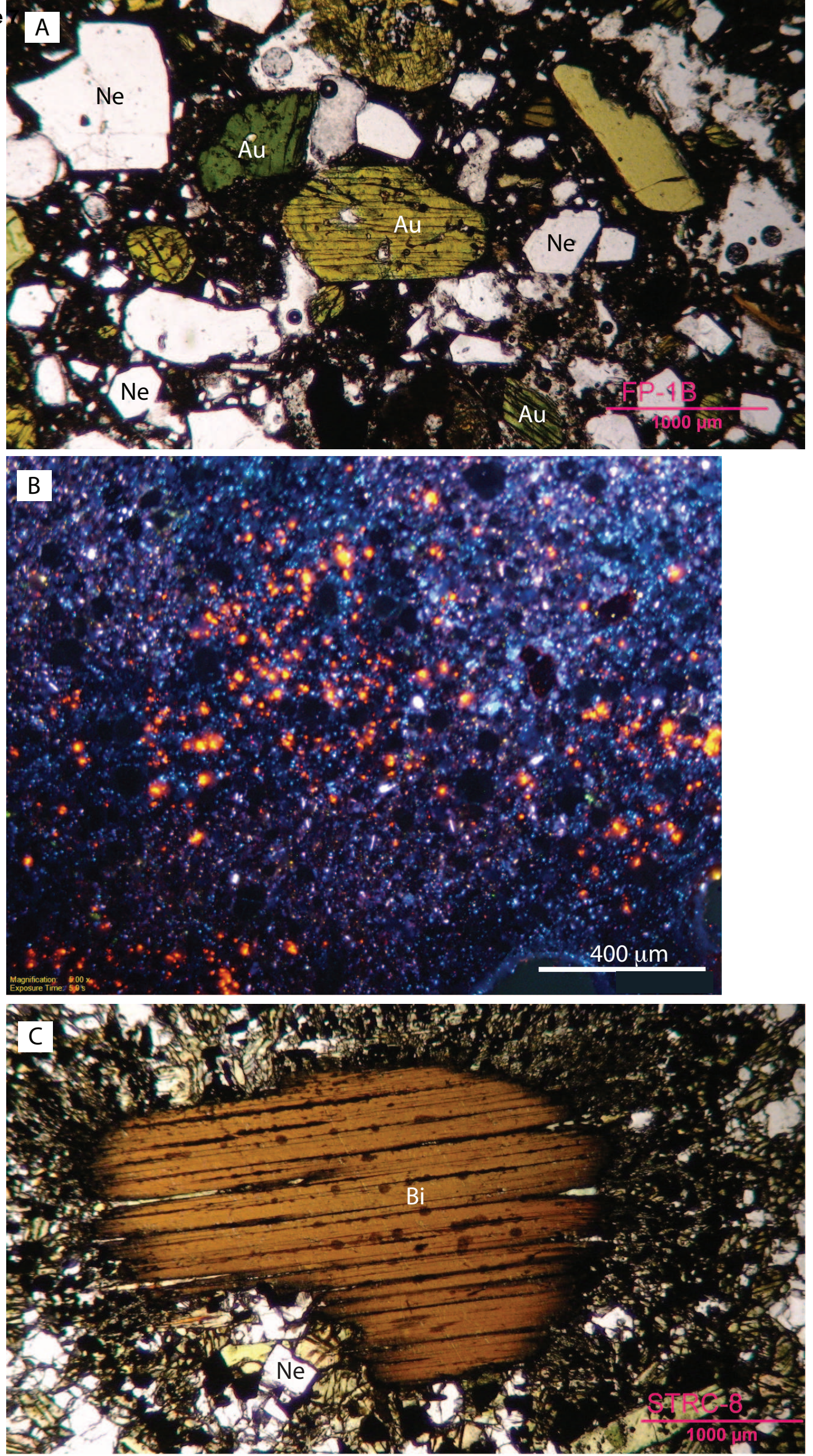

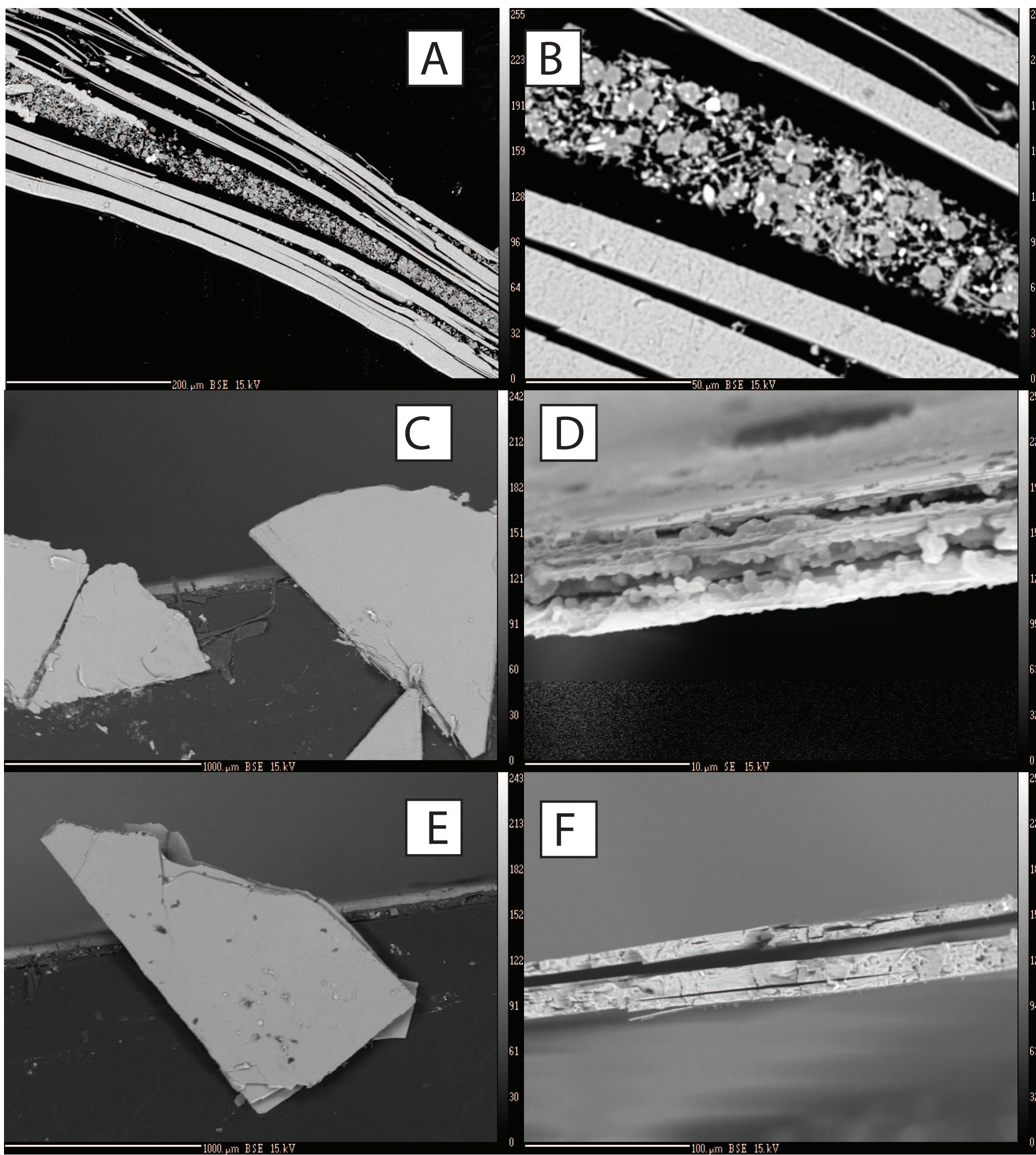

Liutkus et al., Figure 8 
Figure 9

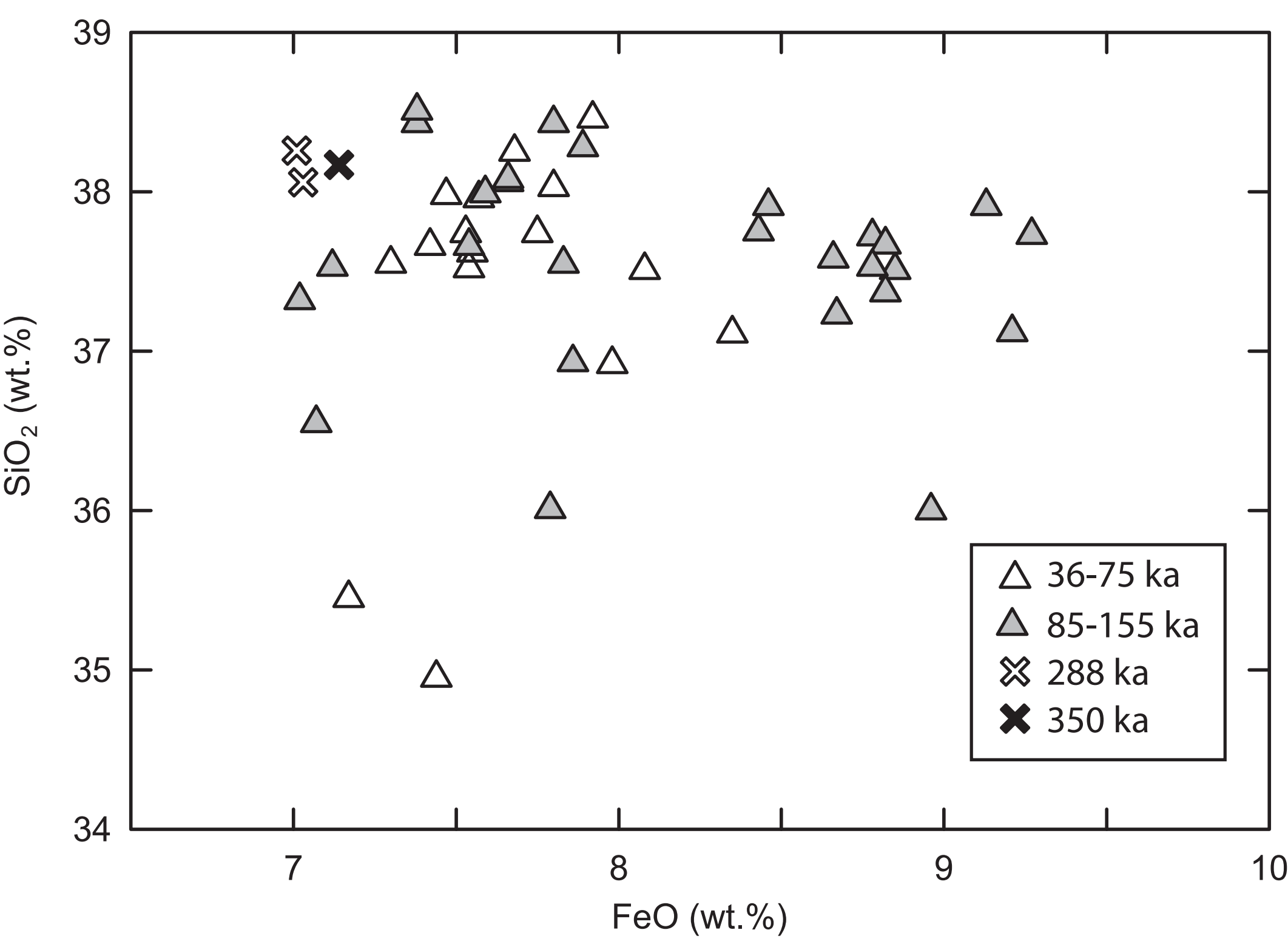

Liutkus et al., Figure 9 

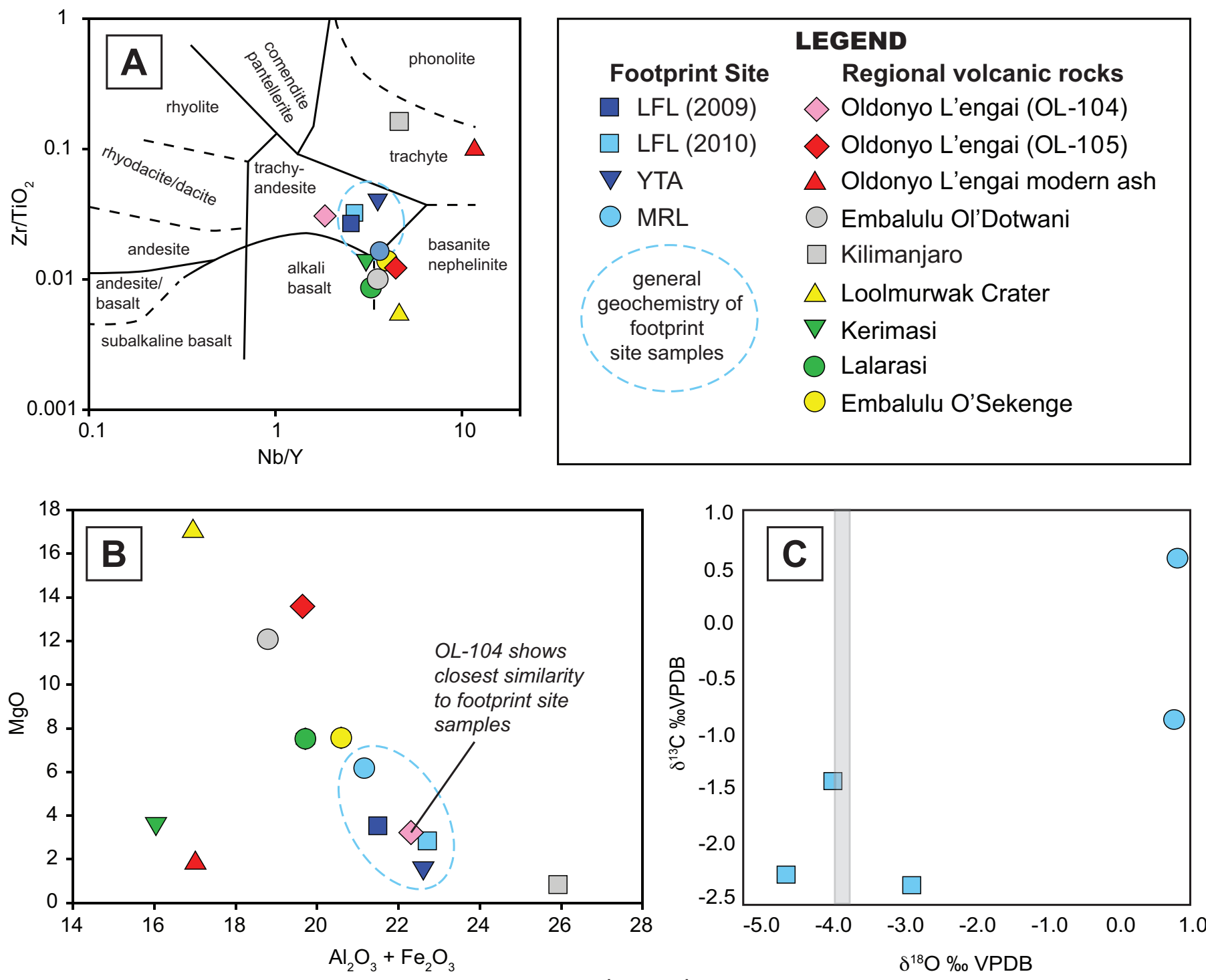

Liutkus et al., Figure 10 


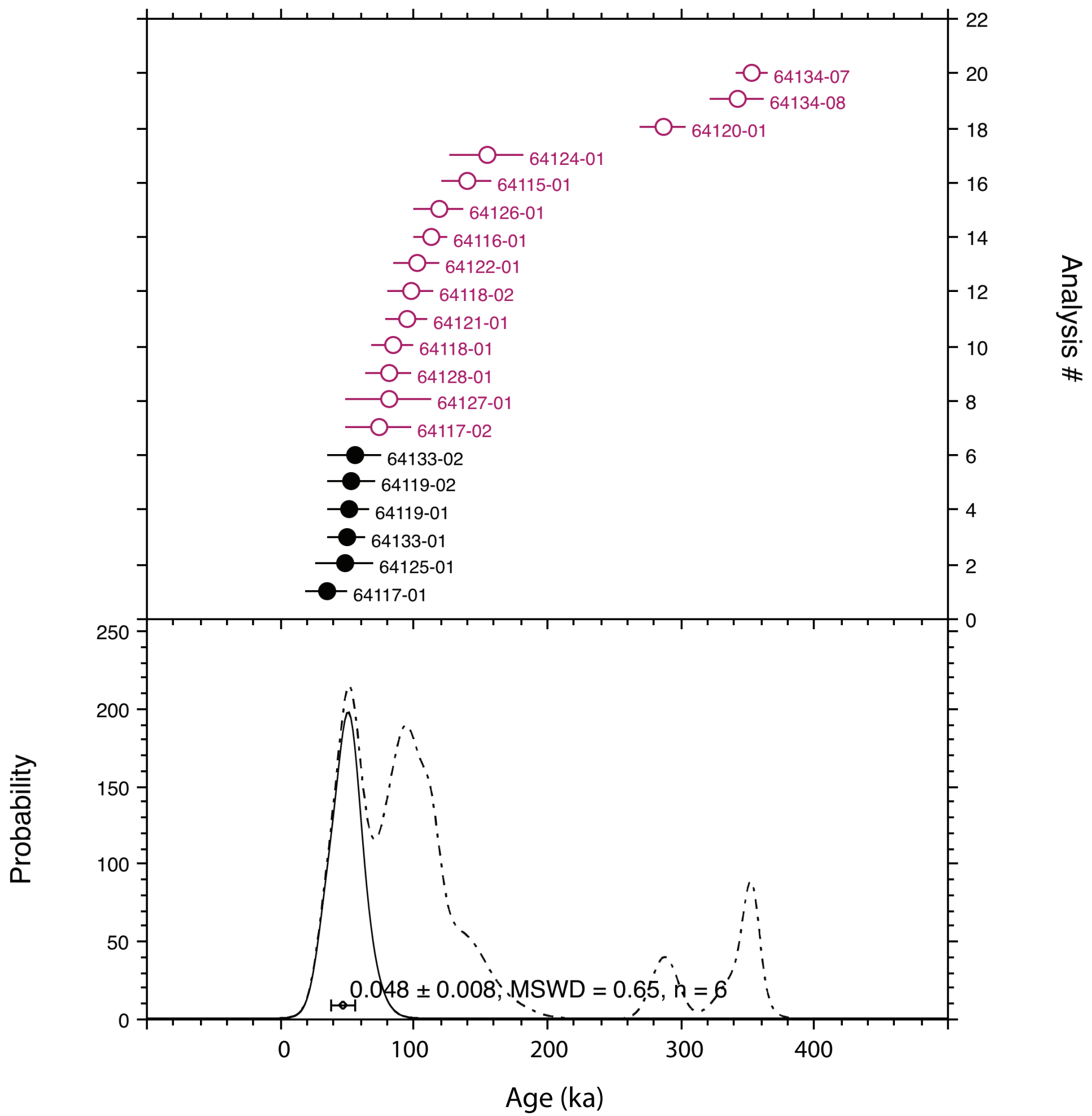

Liutkus et al., Figure 12 


\begin{tabular}{|c|c|c|c|c|}
\hline \multicolumn{5}{|c|}{ Footprint Roconstruction Chemistry } \\
\hline Sample & Blank & Freshwater Spring & Hot Spring & Lake Natron \\
\hline$\overline{\mathrm{pH}}$ & 7.49 & 7.56 & 9.37 & 8.86 \\
\hline Salinity (ppt) & 0.05 & 1.11 & 9.18 & 56.61 \\
\hline TDS (g/L) & 0.064 & 1.404 & 10.19 & 52.56 \\
\hline Conductivity ( $\mathrm{S} / \mathrm{cm})$ & 94 & 2049 & 14779 & 76323 \\
\hline Temperature $\left({ }^{\circ} \mathrm{C}\right)$ & 22.3 & 22.4 & 22 & 22 \\
\hline Hardness & 30 & 30 & 30 & $180+$ \\
\hline Alkalinity (ppm) & 40 & 80 & $240+$ & $240+$ \\
\hline
\end{tabular}

Table 1. Chemistry of fluid solutions reacted with modern ash in footprint-stability experiments. 
Primary minerals:

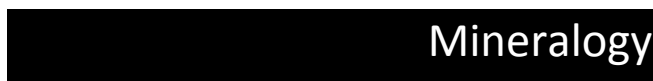

\section{OL-104}

Nepheline

Augite

Titanite

Muscovite

\section{BL}

Nepheline Augite Titanite Muscovite Magnetite Leucite Apatite Wollastonite CancriniteVishnevite Hornblende
Nepheline Augite Titanite Biotite Magnetite Leucite MRL

Nepheline

$$
\text { Calcite }
$$

Augite --

Biotite Magnetite Melilite Phillipsite Magadiite

Calcite Phillipsite Calcite Phillipsite Trona

Calcite
Phillipsite
Trona

Secondary minerals: Magadite

Table 2. Mineralogy confirmed by XRD, SEM-EDS, or optical microscopy for footprint site samples and OL-104 (from Oldoinyo L'engai). 
Age Dating Methods Employed

\begin{tabular}{lllll}
\multicolumn{1}{c}{ Unit } & \multicolumn{1}{c}{ Method } & \multicolumn{1}{c}{ Material } & \multicolumn{1}{c}{ Lab } & \multicolumn{1}{c}{ Result } \\
LFL & ${ }^{14} \mathrm{C}$ & plant & Beta Analytic & N/A (no carbon) \\
LFL & ${ }^{40} \mathrm{Ar} /{ }^{39} \mathrm{Ar}$ & hornblende & Berkeley Geochronology Center dates)
\end{tabular}

Table 3. Age dating methods employed for various units at the footprint site. 